Article

\title{
The Use of the Death Penalty for Drug Trafficking in the United States, Singapore, Malaysia, Indonesia and Thailand: A Comparative Legal Analysis
}

\section{Yingyos Leechaianan ${ }^{1, *}$ and Dennis R. Longmire ${ }^{2}$}

1 Faculty of Police Science, Royal Police Cadet Academy, 90 Moo 7 Amphur Sampran, Nakornpathom 73110, Thailand

2 College of Criminal Justice, Sam Houston State University, 816 17th St. PO Box 2296, Huntsville, TX 77342, USA; E-Mail: icc_drl@shsu.edu

* Author to whom correspondence should be addressed; E-Mail: yingyos3535@gmail.com; Tel.: +668-4804-3535.

Received: 26 March 2013; in revised form: 27 May 2013 / Accepted: 28 May 2013/ Published: 5 June 2013

\begin{abstract}
This article assesses the use of capital punishment for drug trafficking and related crimes from a comparative perspective. Domestic narcotics legislation, as well as important drug trafficking cases in four Southeast Asian nations (Singapore, Malaysia, Indonesia, and Thailand) are examined in-depth and compared to the United States, which plays an important role in eradicating global drug-related problems. This article contends that the use of capital punishment is disproportionate to the gravity of drug-related offenses and that international drug control and enforcement treaties never suggested using such sanctions to deter crime. Fortunately, four Southeast Asian countries in this study, including Singapore, Malaysia, Indonesia and Thailand, currently realize this disproportionality and have become reluctant to carry out executions for drug trafficking; even though they continue to sentence a large number of drug-related offenders to death annually, they do not actually carry out these executions. Future research related to this topic is also recommended in this article.
\end{abstract}

Keywords: drug trafficking; capital punishment; Southeast Asian; death penalty; narcotics; comparative law 


\section{Introduction}

For many decades, drug trafficking has posed a major threat to the international community [1,2]. It cannot be denied that drug problems not only weaken the moral fabric of the society, but often occur concurrently with other crimes (e.g., bribery, corruption or even murder) [2]. Drug problems negatively affect users, their friends, families and even the whole society. ${ }^{1}$ The United Nations Office on Drugs and Crime (UNODC) has estimated that approximately 210 million people have used illicit drugs and approximately 200,000 people have died due to narcotics ([5], p. 8). Some studies further indicate that drug abuse is closely related to the widespread distribution of infectious diseases, especially HIV [5]. UNODC further notes that drug trafficking is a transnational crime diverting billions of US dollars annually from the legitimate global marketplace [5]. In 2009 alone, the value of the global cocaine market was estimated to be US \$ 165 billion and the global opiate market was valued at US \$ 68 billion [5]. Consequently, many nations, as well as the United Nations, put a great deal of effort into both international and domestic narcotics control, including researching, monitoring and taking serious legislative actions against drug trafficking [5,6].

It should also be pointed out that the border areas of three Southeast Asian countries referred to as the "Golden Triangle" (Thailand, Laos and Burma) are responsible for the world's second largest market of narcotics, especially opium [2]. Specifically, the opium poppy production in the Golden Triangle has a significant impact on the total global trend of opium production, and opium from these areas is particularly likely to be trafficked through Middle Eastern and African routes to destinations in the US and Europe [2,5]. In addition, the highest rate of methamphetamine abuse in the world occurs in Thailand, and according to an UNODC report, 0.2 percent of the total population of Malaysia is addicted to opiates [2]. Accordingly, it was not surprising when many countries in Southeast Asia began imposing very harsh penalties on drug trafficking when compared to other nations [2]. Paradoxically, although there is a global trend toward the abolishment of the death penalty, many Southeast Asian countries have authorized its use for myriad drug-related offenses, and in some instances, these countries have established a mandatory death penalty for drug trafficking offenses [2]. The use of capital punishment for drug trafficking offenses has consistently been a controversial issue in the global community, since it is related to human rights issues [1,6-9].

This study concentrates primary attention toward the use of capital punishment for drug trafficking offenses in Singapore, Indonesia, Malaysia and Thailand, since the use of the death penalty for such crimes in these four countries is being vigorously debated by legislators, government officials in many countries, as well as international organizations [10-12]. Specifically, many argue against the imposition of the mandatory death penalty for drug trafficking offenders in Malaysia and Singapore, since they consider such sanction to be in violation of international human rights laws [13]. Also, in 2003, the UN Human Rights Committee was alarmed by Thailand's policies related to the war on drugs, which led to the execution of about 2,800 alleged drug traffickers being executed [14]. Moreover, as with the other three countries being focused upon in this article, the international community has raised serious concerns about the number of death row inmates in Indonesia, since it is

e.g., "Heroin addict parents kill child with drug overdose.” [3] and “Thai drug organization blamed for killing 13 crew members on Chinese cargo ships.” [4]. 
estimated that more than half of those sentenced to death are drug trafficking offenders [8]. This study does not examine Myanmar, Brunei Darussalam and Laos, because these three countries have abolished the death penalty for drug-related crimes in practice [15].

This study is significant in many aspects. First, it contributes to today's debate questioning whether drug trafficking offenses fall within the scope of the most serious crimes for which capital punishment can be applied $[8,15]$. Second, this study provides essential information describing the worldwide trend toward the abolition of the death penalty. In addition, while capital punishment for drug trafficking has gained a lot of attention from academia [1,6-9], only a few studies have examined the use of this sanction in Southeast Asian countries from a comparative legal perspective [2]. It cannot be denied that a comparative legal study is beneficial for legislatures and policy makers, since it informs differences and similarities about narcotics legislation, policies and precedents among different countries, giving them a clear picture of how different nations are approaching this serious problem.

In sum, this article contends that important international drug control and enforcement treaties, as well as international drug control agencies have never supported the use of capital punishment to deter drug trafficking and drug-related crimes, neither in Southeast Asian nations nor in any other countries with serious drug problems. Even the US, which plays an essential role in efforts to eliminate drug-related problems in the world, is highly unlikely to impose the death penalty on offenders convicted solely of a drug trafficking offense. Therefore, after comparing and contrasting domestic narcotics laws and important capital drug-related cases in four Southeast Asian countries and the US, this article recommends that the use of capital punishment is disproportionate to the gravity of drug-related offenses. Specifically, four Southeast Asian countries, including Singapore, Malaysia, Indonesia and Thailand, understand this issue and are currently reluctant to carry out executions, even though there are a large number of death-row inmates for drug offenses.

\section{A Brief History of the Use of Capital Punishment for Drug Trafficking Offenses}

\subsection{Government Practices Responding to Capital Drug Crimes}

To date, the worldwide trend toward the use of capital punishment has decreased consistently since the United Nations announced the more general goal of abolishing the death penalty worldwide [1,2]. In contrast to the global movement toward abolishing capital punishment, many countries have recently enacted domestic legislation allowing capital punishment for drug crimes [8]. Specifically, since 1986, seven countries, Bangladesh, Guyana, Qatar, Saudi Arabia, Sudan, the Philippines and Vietnam, have passed laws extending the penalty for drug offenses to include capital punishment ${ }^{2}$ Even though there are conflicting reports about the precise number of countries that retain the death penalty for drug-related offenses ${ }^{3}[8,15]$, there is no dispute that most of those countries are likely to be Middle Eastern and Southeast Asian nations [8].

2 Lines reports that from 1987-1992, Bangladesh, Qatar, Saudi Arabia, Guyana, Sudan, and Vietnam first introduced capital punishment for drug crimes. The Philippines reintroduced such sanctions again since they abolished capital punishment for all crimes in 1987 [8].

3 According to Lines, globally, there are 26 countries that reserve capital punishment for drug offenses, including Bahrain, Bangladesh, Brunei Darussalam, China, Egypt, Guyana, Indonesia, Iran, Iraq, Jordan, South Korea, Kuwait, 
In fact, the exact number of nations having capital drug crimes is unclear, since some countries that have legislation allowing for the use of capital punishment for drug offenses have actually abolished it in practice [15]. To clarify this confusion regarding the use of capital punishment for drug crimes among Southeast Asian countries, this article classifies the governmental practices responding to capital drug crime into three categories: (1) retentionist, (2) de facto abolitionist and (3) abolitionist. Retentionist countries include nations where their judicial branches have the authority, empowered by domestic legislation, to impose the death penalty on drug trafficking offenders and who actively exercise such powers [2]. The retentionist countries in Southeast Asia include Singapore, Malaysia, Thailand and Indonesia.

In Singapore and Malaysia, two nations with mandatory death sentences for offenders convicted of drug trafficking offences, it is estimated that more than half of those executed annually are convicted of drug-related offenses. There are, however, no government reports documenting the annual number of executions in these countries [8,15]. The International Harm Reduction Association reports that Singapore has the highest execution rate in the world, noting that the Singapore government has executed 326 death-row inmates for drug offenses since 1991 [8,16]. Additionally, in Singapore, about 76 percent of those executed between 1994 and 1999 were convicted of drug-related offenses ([8], p. 9). William Schabas further reports that between 1999 and 2003, 110 out of 138 death-row prisoners whose executions were carried out in Singapore were for drug-related offenses ([15], p. 4). However in recent years, the number of executions in Singapore has declined significantly. The number of those executed for drug offences in 2011 was two. In addition, Singapore's legislative body has recently reconsidered the application of the death penalty for drug offenses [16]. Amendments to their Misuse of Drugs Act specifying two conditions where capital punishment will not be mandatory for drug trafficking were adopted in mid-2012 ([16], p. 29). This legislation allows traffickers to apply to have their execution sentence changed to life imprisonment if having satisfied two conditions [16]. Specifically, the two conditions are (1) "the trafficker must have only played the role of courier and must not have been involved in any other activity related to the supply or distribution of drugs and (2) discretion will only apply when either the trafficker has cooperated with the Central Narcotics Bureau in a substantive way or he or she has a mental disability, which substantially impairs his appreciation of the gravity of the act” ([16], p. 29).

In Malaysia, the International Harm Reduction Association noted that, based on a report from the Malaysian Internal Security Ministry, over the past thirty years, 229 death-row inmates convicted of drug crimes have been executed ([8], p. 9). Schabas also indicated that 50 out of 68 death-row prisoners who were executed in 2009 had been convicted of committing drug crimes ([15], p. 3). However, like Singapore, Malaysia today seems to reflect the global trend toward the abolition of the death penalty for drug offenses. The number of those sentenced to death between January and August

Malaysia, Myanmar, the Philippines, Qatar, Saudi Arabia, Singapore, Sri Lanka, Sudan, Syria, Taiwan, Thailand, the United Arab Emirates, the United States of America and Vietnam [8]. By contrast, Schabas claimed that 32 countries have capital punishment for drug-related offenses, including Bangladesh, Bahrain, Brunei-Darussalam, China, Cuba, Egypt, India, Indonesia, Iran, Iraq, Kuwait, Laos, Libya, Malaysia, Myanmar, North Korea, Oman, Pakistan, Palestine, Qatar, Saudi Arabia, Singapore, South Korea, Sri Lanka, Sudan, Syria, Thailand, Taiwan ROC, United Arab Emirates, United States of America, Vietnam and Yemen [15]. 
for drug offenses was reduced to around 44 in 2012 ([16], p. 30). In addition, the government is now considering replacing the mandatory death penalty with life imprisonment. Specifically, in October of 2012, the government considered imposing a moratorium on executions for those who are on death row for drug offenses ([16], p 30). In both Thailand and Indonesia, even though these two countries have high death-sentence rates for all crimes, executions for these offenses have rarely been carried out $^{4}$ [15]. The Thai Department of Correction reported that 12 out of 281 executions carried out between 1935 and 2001 were for drug offenses [17]. Schabas also indicated that over the past six years, there was only one execution for a drug-related offense in Thailand, which took place in 2009 ([15], p. 4). In Indonesia, 56 out of 110 death-row prisoners are awaiting execution for drug offenses; however, no drug-related execution has been carried out since 2009 ([15], p. 4).

De facto abolitionist countries refers to those nations where the use of the death penalty for drug crimes is included in their domestic statutes, but the sanction has not been carried out over the past ten years [2]. These countries include Laos, Myanmar and Brunei-Darussalam ([15], p. 4). Abolitionists are those countries in which capital punishment for drug offenses has already been abolished, including the Philippines and Cambodia [15].

\subsection{Three Essential International Treaties and Drug Control Agencies}

It is important to discuss three specific international treaties and other drug control agencies, since they significantly affect drug control systems and influence domestic legislation and policies responding to drug offenses across Southeast Asian countries. The United Nations considered drug trafficking to be a global issue that could only be addressed by worldwide cooperation [5]. Consequently, the United Nations established three important international Drug Control and Enforcement Treaties: (1) the 1961 U.N. Single Convention on Narcotics Drugs, (2) the 1971 U.N. Convention on Psychotropic Substances and (3) the 1988 U.N. Convention against Illicit Traffic in Narcotic Drugs and Psychotropic Substances $[2,18]$. The primary purpose of these drug control and enforcement treaties is to "decimate the market for illicit drugs, such as cocaine, heroin and methamphetamines, while also promoting the availability of licit drugs, such as narcotic pain medication, which are used for medical and scientific purposes” ([18], p. 823).

The 1961 UN Single Convention on Narcotic Drugs focuses on the agricultural production of drugs, as well as the formation of a drug scheduling system used to categorize the level of control appropriate for both illicit and licit drugs [18]. In fact, both the 1961 UN Single Convention on Narcotic Drugs and the 1971 UN Convention on Psychotropic Substances have a similar key purpose encouraging the accessibility of legal drugs for therapeutic intentions. They were not expressly developed to suppress the illegal drug trade [18]. However, the 1971 Psychotropic-Substances Convention, unlike the 1961 UN Single Convention on Narcotic Drugs, did not restrict the manufacture of psychotropic drugs, but instead limits the use of such substances [19]. In contrast to both the 1961 and 1971 UN Conventions, the 1988 U.N. Convention against Illicit Traffic in Narcotic Drugs and Psychotropic Substances has targeted global drug trafficking as its main goal by requiring all members of the United Nations to pass domestic statutes that include drug trafficking on the lists of the criminal offenses, to cooperate in

4 These two countries do not use the death penalty as a routine part of their drug enforcement regimes, despite the presence of such laws in the books. 
international efforts to combat drug trafficking across nations and to allow for the confiscation of properties and equipment used in narcotic-trafficking offenses [18,19]. International drug control agencies that have been given responsibility to execute drug control treaties include: (1) the United Nations International Narcotics Control Board (INCB); (2) the Commission on Narcotics Drugs (CND); (3) the United Nations Office on Drugs and Crime (UNODC); (4) the Office for Drug Control and Crime Prevention (ODCCP); and (5) the World Health Organization (WHO) [18]. The purpose of INCB is to assist and provide guidance to all countries' members in drug-related issues; however, in practice, INCB has neither direct nor indirect power against countries reluctant to suppress illegal drug producing and manufacturing [18]. The major responsibility for CND is to draft narcotic drug policies and agreements for UNODC to implement. The ODCCP was recently established in 1997 with the sole purpose of addressing drug trafficking. In other words, CND, UNODC and ODCCP focus mainly on addressing narcotic issues [18]. By contrast, the World Health Organization (WHO) only considers which drugs should be classified as illegal or legal. The WHO can only provide recommendations; they have no ability to enforce the policies of other international drug control agencies [19].

\subsection{The US Role in Narcotics Control Legislation and Policies of Southeast Asian Countries}

The US plays an important role in addressing the international narcotics problems by utilizing the Anti-Drug Abuse Act of 1988 to set up new programs, activities or even new standards for all countries, which have problems with the production, manufacturing and trafficking of narcotics. In particular, the US has both mandatory and discretionary sanctions available for countries that have problems associated with illicit drug production or transportation and who do not pass specific requirements discussed below. Possible sanctions include loss or reduction of US foreign aid, as well as trade sanctions, including the denial of preferential tariff treatment to a country's exports under GSP or refusal of loan requests from international institutions $[6,20]$. By contrast, countries passing the requirement are qualified to receive full assistance.

The requirement of the international policies influenced by the Anti-Drug Abuse Act of 1988 allows the US to impose sanctions against countries determined by the extent to which they fully cooperate with the US in controlling narcotic production, transportation and trafficking [20]. For countries reported to be major narcotics producers, there are three essential steps required before being certified as cooperative. These steps include “(1) putting a great deal of effort in preventing legal narcotic from being diverted into the illegal market, (2) maintaining narcotics at the level of legal demand, (3) preventing the illegal cultivation and production of this commodity” ([20], p. 25). This process, called certification, usually starts at the beginning of each fiscal year under consideration by the US President. After the US President identifies which countries are not eligible to receive full aid, the US Congress has 45 days of continuous sessions to assess the US president's determinations [20]. Accordingly, it cannot be denied that the Anti-Drug Abuse Act of 1988 not only has had a significant impact on narcotic legislation and policies among Southeast Asian nations, but on those of other countries with drug-related problems, as well. 


\subsection{The Association of South East Asian Nations (ASEAN) Drug Control System}

In 1967, the Association of South East Asian Nations (ASEAN) was founded with the main purpose of fostering cooperation among all member states in terms of drafting common legislation, policies, strategies and activities in economic, cultural, scientific and, more importantly, law enforcement areas [21]. Specifically, the ASEAN principles responding to drug trafficking problems were first declared in Manila, Philippines, in 1967. To put these principles into practice, ASEAN holds an annual Drug Experts Group Meeting to facilitate the exchange of information on effective legislation, as well as law enforcement policies combating narcotic drug trade in Southeast Asia [21]. Moreover, in 1982, all member countries agreed to establish the ASEAN Narcotic Desk with two objectives: (1) providing information related to narcotic issues to ASEAN Secretariat and (2) organizing activities and programs that can enhance performance level in fighting drug trafficking problems [21].

The UNODC reported that the ASEAN Narcotic Desk plays an important role in improving cooperation among Southeast Asian countries, sometimes known as the drug-producing region, in solving narcotic-trafficking problems. Based on the severity of the narcotic problems in Southeast Asia, ASEAN member countries seem likely to respond to drug-related problems by increasing the penalties available for those committing drug offenses. An example of activities responding to drug trafficking developed by ASEAN is the incorporation of "preventive detention, the seizure of major drug traffickers and the confiscation of passports of convicted drug traffickers" into their member states' anti-narcotic domestic legislation ([21], p. 55). Consequently, it is not surprising that in this region, capital punishment is commonly used as a method to keep the narcotic drug trade from getting out of hand.

In sum, the history clearly demonstrates that narcotic-trafficking problems are currently being addressed through a comprehensive treaty regime and with the cooperation among the international, as well as regional communities [19]. However, no international drug control treaties have imposed any requirements regarding the availability of the death penalty for drug trafficking and related crimes [1,2].

\section{Literature Review}

Amnesty International provides four arguments against the use of the death penalty for drug offenses [1]. First, they contend that countries that impose mandatory capital punishment on drug trafficking (e.g., Singapore and Malaysia) take great risks of imposing such sanctions on drug addicts rather than drug traffickers, who are the main target of anti-narcotics legislation [1]. It should be noted that many countries (e.g., the US) consider an illicit drug user to be a patient more than an offender. Further, due process of law appears to be in question when a government uses mandatory death sentences negating judges' ability to exercise discretion regarding sanctions based on the circumstances of particular cases. It is obvious that the death penalty is not appropriate for all narcotics cases [1]. That is, capital punishment is too severe when compared to the gravity of the offenses it is being used against. In addition, the use of capital punishment increases the risk of executing the innocent, since it is irrevocable [22].

The second issue raised in objection to the use of capital sanctions in drug-related cases is the lack access to a fair trial [1]. Amnesty International argues that the introduction of capital narcotic crimes in 
many countries' domestic legislation has weakened the international standard for a fair trial, noting that in some countries (e.g., China, Saudi Arabia, Malaysia and Indonesia) safeguards for a fair trial have been diminished for suspected drug offenders [1]. An example of problems associated with fair trials in these cases, noted by Amnesty International, took place in the Manusami case in Indonesia in 1985 [1]. In this case, Maniam Manusami, a Malaysian, was arrested for trafficking heroin into Indonesia. Manusami confessed to the police officer that he smuggled the heroin, but he said Chan Ting Chong, a Malaysian businessman, paid him to do so. As a result, while the court imposed life imprisonment on Manusami, Chan Ting Chong was arrested and, later, sentenced to death even though he denied any association with Manusami. Manusami later filed a petition to the Supreme Court, stating that he falsely involved Chan Ting Chong. Manusami reported that he did not know Chan Ting Chong personally. He had just came across Chan Ting Chong at the airport a few days before getting arrested; however, the court refused to consider any mitigating factors and rejected Chan Ting Chong's appeal. Consequently, Chan Ting Chong was executed in January 1995. Another example of the limitations in the delivery of a fair trial in drug-related cases involves the Escandar case, since the Malaysian Supreme Court sentenced Hassim Escandar, a Filipino worker, to death based only on police evidence in 1993 [13].

The lack of evidence that the threat of capital sanctions serves as an effective deterrent impact is the third argument Amnesty International raises against the use of capital punishment for drug trafficking. It is unquestionable that the narcotics trade in many countries (e.g., Saudi Arabia, Iran, China and Malaysia) is still increasing despite the introduction of mandatory death sentences for these crimes [13]. In Malaysia, although there had been more than 200 people executed since 1975, the 2004 report from INCB indicated that the availability of heroin in Malaysia had increased, due to the rising demand for the drug [13,23]. Amnesty International further points to the Malaysian Inspector General of Police's report published in 1985, noting that the death penalty was considered to be an ineffective deterrent on narcotic traffickers, evidenced by the increasing number of drug traffickers entering the market [1]. Colman Lynch similarly notes that the death penalty is less likely to have a deterrent impact on illicit drug traffickers in Indonesia, since it is a crime providing high profits [10]. They also observe that when Indonesian law enforcement agencies focus more attention on one illicit drug over another, traffickers simply change their focus toward other types of drugs. As a result, Lynch suggests that the best way to address narcotic problems is to focus on it from the demand side rather than the sanction side [10].

The use of capital punishment in drug offenses is directly related to human rights issues, especially issues associated with: (1) the right to life; (2) the right to be free from cruel, inhumane and degrading treatment or punishment; and (3) the right to a standard of living adequate for health and well-being [18,24]. Sita Legac provides Thailand as an example, where citizens' human rights have repeatedly been violated through the use of narcotic laws and law enforcement policies. In Thailand, an offender convicted of illicit drug trafficking can face the maximum penalty (capital punishment) or lesser penalties that are still harsher than those of other countries (long-term imprisonment under very harsh conditions plus heavy fines) [18]. Further, in 2003, the Thailand Government announced a war on drugs policy, which imposed very harsh sanctions, including extrajudicial killing of suspected narcotic offenders [25]. As a result, there were more than 2,800 people killed during the policy's implementation [25]. Legac suggests that UN drug control agencies, including CND, INCB and 
UNODC, need to take serious actions to assist those countries where citizens' human rights have consistently been violated [18]. As he points out, the most effective response is to provide such countries practical alternatives to their current anti-narcotic laws that sacrifice citizens' human rights, while continuing to impose some penalty on the countries where such recommendations are ignored [18].

In sum, Lines points out that countries using the death penalty for drug offenses should provide official data regarding the number of executions, so as to find out whether the increased penalties work or not [8]. It is impossible to assess the claim that the mandatory death sentences succeed in deterring narcotic trade without official statistics of both crimes (narcotic offenses) and the number of executions [8]. Singapore is one of many countries (e.g., China) claiming to be successful in deterring drug trafficking problems despite the inaccessibility of the official data [8]. Finally, the international community should devote their attentions to the violation of international human rights safeguards among the countries, which use very harsh punishment on drug offenders.

\section{The International Human Rights Law and Capital Drug Trafficking Punishment}

\subsection{Article 6(2) of the International Covenant on Civil and Political Rights (ICCPR)}

The International Covenant on Civil and Political Rights (ICCPR) was adopted by the United Nations General Assembly in December 1966 [26]. The significance of the ICCPR is that it is the first time the UN recognized capital punishment as a global concern and expressly announced the goal of abolishing the death penalty across all countries [8]. As the Office of the UN High Commissioner for Human Rights pointed out, even though capital punishment is not prohibited, it is to be limited to only the most serious types of crimes in order to guarantee the human rights for those facing capital punishment [8]. Article 6(2) of ICCPR specifically states that:

"In countries which have not abolished the death penalty, sentence of death may be imposed only for the most serious crimes in accordance with the law in force at the time of the commission of the crime and not contrary to the provisions of the present Covenant and to the Convention on the Prevention and Punishment of the Crime of Genocide. This penalty can only be carried out pursuant to a final judgment rendered by a competent court" [26].

One of the most important problems associated with article 6(2) of the ICCPR is the lack of a definitive statement regarding what constitutes the most serious crimes. This makes it complicated when trying to determine whether drug trafficking and related offenses fall within the purview of the most serious crimes or not [8]. As a result, the unclear definition of this term under Article 6(2) of ICCPR has consistently led to the arbitrary exercise of the death penalty, which, in turn, harms citizens' human rights in many countries. Two important human rights issues likely to be violated when sanctioning those facing the death penalty include: (1) the right to be free from cruel and inhumane punishment; and (2) the right to have an adequate standard of living essential for health and well-being [8,18].

In accordance with the UN's goal of abolishing the death penalty, the most serious crimes should be interpreted as life-threatening offenses or crimes that result in loss of life. Even though the meaning of the term most serious might vary widely across all countries due to social, religious and political 
culture, the interpretation of such a term that goes far beyond life-threatening crimes (e.g., economic crimes and victimless crimes) does not meet the threshold of the most serious crimes under ICCPR standards [8]. Similarly, many UN agencies (the UN Human Rights Committee, the UN General Assembly, the Economic and Social Council of the UN, UN Special Rapporteur and the UN Secretary-General) have reached an agreement in the term most serious under ICCPR, noting that they tend to limit capital punishment to intentional crimes with deadly outcomes (e.g., homicide) [8]. Specifically, the UN Secretary-General stated that countries apply the death penalty to crimes that do not result in death is problematic ${ }^{5}$ [8]. Despite the absence of a definitive meaning for the term of what constitutes the most serious crimes under ICCPR, it is clear that there is an implicit consensus that the meaning of most serious under ICCPR is restricted to crimes that directly result in the loss of life [8].

\subsection{Drug Trafficking Crime and the Interpretation of the Most Serious Crime}

The procedure recommended by the International Harm Reduction Association that can be used to assess whether drug trafficking crimes are among the most serious crimes under ICCPR involves an analysis of the domestic legislation of those countries having drug trafficking offense as a capital crime [8]. It is obvious that the definition of drug trafficking crime among retentionist countries is dissimilar. For example, the amount of heroin possession triggering the death penalty in Singapore is 15 grams of pure heroin (equivalent to 750 grams of normal heroin). This compares with 15 grams of normal heroin in Malaysia and 20 grams of normal heroin in Thailand [2,8]. Further, 200 grams of cannabis can trigger the death penalty in Malaysia compared to 500 grams in Singapore [2]. Since a capital drug crime in one country might only be a minor offense in another country, the absence of consistency among retentionist countries in the amount of illicit drugs that trigger the death penalty leaves a questionable definition of whether drug trafficking and related offenses are legitimately considered to be among the most serious crimes [8]. This disparity not only weakens any potential utilitarian purpose for the use of the death penalty, but demonstrates the arbitrary nature of any policy considering drug offenses among the list of most serious crimes, as well [8].

However, retentionist countries usually justify the use of practices that do not fully follow the international human rights norms through the notion of cultural relativism [27]. That is, "different cultures have different traditions, so each culture's rights to traditions are to be considered valid, because they should be judged based on the culture from which they have sprung and not based on Western-derived international law norms” ([27], p. 551). Therefore, the use of capital punishment for drug trafficking crimes among Southeast Asian countries can be supported through this notion, since Southeast Asia also has its own regional or cultural norms. In 1993, the Asian regional meeting, pursuant to General Assembly resolution 46/116 of December 17, 1991, in the context of preparations for the World Conference on Human Rights, was held in Bangkok, and the essence of this meeting was development and discussion of the Bangkok Declaration that refused to accept the application of the international human rights standard in Asia [27]. Instead, the Bangkok Declaration, headed by China,

5 The Report conducted by the Office of the United Nations High Commissioner for Human Rights in 2006 recommended that China reduce the scope of capital crimes by excluding economic and victimless crimes from the list of crimes for which capital punishment is allowable. 
put a great deal of effort into establishing a regional human rights standard, which has distinctive characteristics appropriate for Asian countries [27].

\section{The Use of the Death Penalty for Drug Trafficking Offenses in the United States}

\subsection{The US Legal System}

Unlike Southeast Asian countries, the US judicial system consists of a federal court system and the different state, county and municipal level court systems [28]. In the US, the governmental structure is divided based on the concept of federalism, created by the US Constitution [28]. Federalism refers to the separation of power, noting that the US government grants the federal government certain powers (external affairs and matters of national concerns, e.g., supporting armies and regulating interstate commerce), while reserving the rest for the state and local governments [ordinary powers of internal government (e.g., controlling elections and public health)] [28].

The federal court system consists of two types of courts: (1) Article III courts, including the US Supreme Court; and (2) courts created by Congress, including magistrate courts and US tax courts. State court systems vary across all states; however, state court systems are likely to consist of: (1) trial courts, (2) intermediate appellate courts and (3) the highest state courts [28]. An offender suspected of drug trafficking and related offenses in the United States can be tried at both federal and state court levels, depending on which laws are applied to an offender [28]. It should be noted, however, that for comparable purposes, this study only focuses on federal-level narcotic laws ${ }^{6}$.

\subsection{The Controlled Substances Act and the Anti-Drug Abuse Act of 1988}

The Controlled Substances Act, sometimes known as the Comprehensive Drug Abuse Prevention and Control Act, was enacted in 1970 with the goal of decreasing narcotics trafficking, as well as controlling substances for medical purposes ${ }^{7}$. This act is also important because it engaged in the creation of the Drug Enforcement Administration (DEA) [6]. Put another way, the agency in charge of enforcing this act is the US Department of Justice, which later founded the DEA to suppress the manufacture and trafficking of illicit drugs, as well as to control substances not only in the US, but in the global community, as well [29].

Under this statute, it is illegal to intentionally "manufacture, dispense, distribute or possess controlled or counterfeit substances," and the penalty for those violating this law depends on the category and quantity of substances involved (21 U.S.C. §841 (1) and (2)) [30]. Specifically, federal trafficking penalties for the five main narcotic types are presented in the Table 1.

6 This is because the main focus of this study is to understand narcotic drug laws of Southeast Asian countries, as compared to that of the United States.

7 The controlled Substances Act composes Title II of the Comprehensive Drug Abuse Prevention and Control Act of 1970 and was codified as 21 U.S.C. §801-§971 [30]. 
Table 1. Federal trafficking penalties by five main types of narcotics (21 U.S.C. §841(b) (1988)) ${ }^{8}$.

\begin{tabular}{|l|l|l|l|l|}
\hline No. & Narcotic & \multicolumn{1}{|c|}{ Quantity } & \multicolumn{1}{c|}{ First Offense } & \multicolumn{1}{c|}{ Second Offense } \\
\hline 1. & Cocaine & $\begin{array}{l}\text { 500-4,999 grams } \\
\text { mixture }\end{array}$ & $\begin{array}{l}\text { 5-40 years imprisonment; } \\
\text { however, 20 years } \\
\text { imprisonment-death penalty if } \\
\text { the case is related to death or } \\
\text { serious injury. }\end{array}$ & $\begin{array}{l}\text { 10 years imprisonment-not } \\
\text { more than life; however, life } \\
\text { imprisonment is imposed if } \\
\text { the case is related to death or } \\
\text { serious injury. }\end{array}$ \\
\hline 2. & Cocaine Base & $\begin{array}{l}\text { 28-279 grams } \\
\text { mixture }\end{array}$ & $\begin{array}{l}\text { 5-40 years imprisonment; } \\
\text { however, 20 years } \\
\text { imprisonment-death penalty if } \\
\text { the case is related to death or } \\
\text { serious injury. }\end{array}$ & $\begin{array}{l}\text { 10 years imprisonment-not } \\
\text { more than life; however, life } \\
\text { imprisonment is imposed if } \\
\text { the case is related to death or } \\
\text { serious injury. }\end{array}$ \\
\hline 3. & Heroin & $\begin{array}{l}100-999 \text { grams } \\
\text { mixture }\end{array}$ & $\begin{array}{l}\text { 5-40 years imprisonment; } \\
\text { however, 20 years } \\
\text { imprisonment-death penalty if } \\
\text { the case is related to death or } \\
\text { serious injury. }\end{array}$ & $\begin{array}{l}\text { 10 years imprisonment-not } \\
\text { more than life; however, life } \\
\text { imprisonment is imposed if } \\
\text { the case is related to death or } \\
\text { serious injury. }\end{array}$ \\
\hline 4. & $\begin{array}{l}\text { Methampheta } \\
\text { mine }\end{array}$ & $\begin{array}{l}\text { 5-49 grams (pure) } \\
\text { or 50-499 grams } \\
\text { (mixture) }\end{array}$ & $\begin{array}{l}\text { 5-40 years imprisonment; } \\
\text { however, 20 years } \\
\text { imprisonment-death penalty if } \\
\text { the case is related to death or } \\
\text { serious injury. }\end{array}$ & $\begin{array}{l}\text { 10 years imprisonment-not } \\
\text { more than life; however, life } \\
\text { imprisonment is imposed if } \\
\text { the case is related to death or } \\
\text { serious injury. }\end{array}$ \\
\hline 5. & Marijuana & $\begin{array}{l}\text { 1,000 or more } \\
\text { kilograms } \\
\text { (mixture); or } \\
\text { marijuana plants } \\
\text { more than life; however, 20 } \\
\text { years imprisonment-death } \\
\text { penalty if the case is related to } \\
\text { death or serious injury. }\end{array}$ & $\begin{array}{l}\text { 20 years imprisonment-not } \\
\text { more than life; however, life } \\
\text { imprisonment is imposed if } \\
\text { the case is related to death or } \\
\text { serious injury. }\end{array}$ \\
\hline
\end{tabular}

In addition, the specific use of capital punishment for a narcotics trafficker was first used in the US in November, 1988, as a part of the Anti-Drug Abuse Act (21 U.S.C. §848 (e)(1)) [31]. Under this Act, the death penalty cannot be imposed on drug traffickers who only manufacture, distribute or deliver controlled or counterfeit substances (21 U.S.C. $\S 848$ (e)(1)) [31]. That is, this act limits the use of death sentences to drug traffickers who engage in a continuing criminal enterprise (C.C.E.) and intentionally kill or cause an intentional homicide (21 U.S.C. $§ 848$ (e)(1)(A)) [31]. It also applies to those who try to avoid being arrested for a felony violation of Subchapter I and II of Chapter 13 under Title 21, as well as anyone who causes the intentional homicide of any federal, state or local law enforcement officers who are on duty (21 U.S.C. $\$ 848$ (e)(1)(B)) [31]. Such narcotics traffickers shall be sentenced between 20 years to life imprisonment or death (21 U.S.C. §848 (e)(1)(B)) [31]. It should be noted that this is the first federal legislation providing the imposition of capital punishment since the Furman case $^{9}$ in 1972 [28]. As US Senator William V. Roth, Jr. of Delaware pointed out, the purpose of this statute is to directly send the message to all drug kingpins that narcotic trafficking will not be

8 Also adapted from Lisa Zilney. Drugs: Policy, Social Costs, Crime, and Justice [6].

9 Furman v. Georgia, 408 U.S. 238 (1972) (holding that the imposition and carry out of the death penalty is cruel and unusual punishment, violating the Eighth and Fourteenth Amendments) [32]. 
tolerated, using the legal concept of a continuing criminal enterprise (C.C.E.), defined as a new crime under this statute, as a vehicle to justify harsher penalties to punish the bosses of the narcotics trade [33,34].

Under the same federal law in the US, an arrested narcotics trafficker will also face asset forfeiture. ${ }^{10}$ The objective of asset forfeiture is to eliminate criminal organizations, so as to prevent future crime, as well as to enhance public safety [6]. The concept of property under 21 U.S.C. §853 includes real property, as well as tangible and intangible personal property (e.g., rights, privileges and claims) [30]. Any person convicted of drug trafficking and related offenses and who was punished by imprisonment for more than one year shall be subjected to forfeit [6]. Also, the provisions of civil forfeiture (sections 881(d)) shall apply to criminal forfeiture. The original scope of the Drug Abuse Prevention Act clearly involves the use of enhanced penalties for all drug trade related offenses and also allows the use of capital punishment for drug traffickers whose actions involve the deliberate loss of life. As enacted, this law ensures that the death penalty will not be imposed on an offender who engages in illicit drug trade without also contributing to the loss of life.

In 1994 through US President Bill Clinton's Federal Death Penalty Act, the US federal death penalty was expanded to include 60 diverse criminal offenses, including operating a large-scale drug enterprise [35]. It is also important to note that under this act, there is no requirement of the killing of a human being to qualify the use of the death penalty. Specifically, under the act, capital punishment can be imposed on a drug kingpin who has to have directed a "continuing criminal enterprise" involving either large quantities of controlled substances ${ }^{11}$ or 20 million dollars in gross receipts from the enterprise over a one year period (18 U.S.C. 3591(b))” ([36], p. 1). However, it is crucial to note that since the enactment of the Controlled Substances Act and the Anti-Drug Abuse Act of 1988, as well as the Federal Death Penalty Act of 1994, the Court is highly unlikely to impose the death penalty on the defendants. To date, only six persons have been sentenced to death under these laws [35]. In addition, the death sentence of one of the defendants, John McCullah, was overturned and commuted to life imprisonment [35]. One of the important reasons for such action is related to the question of whether the act violates the US Constitution's Eighth Amendment prohibition against cruel and unusual punishment [36]. Furthermore, in 2008, the US Supreme Court ruled in Kennedy v. Louisiana that imposing the death penalty on non-homicide crime (rape of a child where the crime did not result in the child's death) would constitute cruel and unusual punishment [37]. In their opinion, mention is made that such action would be in violation of a national consensus on this issue [37].

\subsection{An Important Case: Freeman v. United States (09-10245)}

In January 2005, William Freeman was indicted for multiple charges, including crack cocaine possession, marijuana possession and weapon possession [39]. Freeman pleaded guilty to all charges and received a 106 month jail term under a Federal Rule of Criminal Procedure 11(c)(1)(c) plea agreement. However, three years later, the US Sentencing Commission issued a retroactive amendment

1021 U.S.C. $§ 853$ (1988) [30]. In addition, Calero-Toledo v. Pearson Yacht Leasing Co., 416 U.S. 663 (1974) (ruling that innocent owners' properties can be forfeited with no compensation) [38].

11 The controlled substances under this act are "very large quantities or mixtures of heroin, cocaine, ecgonine, phencyclidine (PCP), lysergic acid diethylamide (LSD), marijuana or methamphetamine” ([36], p. 1). 
to the sentencing guidelines to provide for an equal treatment of powder and crack cocaine offenses, resulting in sentence reductions for individuals sentenced under the former crack cocaine provision. Consequently, Freeman sought to have his sentence reduced under 18 U.S.C. § 3582(c)(2), but the District Court rejected his request [40]. His appeal for a sentence reduction was also denied by the Sixth Circuit Court of Appeal. Freeman later appealed to the US Supreme Court, which granted certiorari and determined that a reversal of the decision was warranted, and the case was remanded for further proceedings [39].

This case is significant because it is related to issues associated with fairness in sentencing guidelines for those convicted of drug offenses. The legal issue of this case is whether a defendant who accepted a Federal Rule of Criminal Procedure 11(c)(1)(c) plea agreement is eligible for a sentencing reduction under 18 U.S.C. § 3582(c)(2) [41,42]. The Sixth Circuit Court denied Freeman's request, holding that a sentence imposed under a plea agreement can be changed only when crucial to evade injustice, and the Freeman case did not fall within this exclusion, since his sentence was still within the new guideline range for his offenses (97-106 months). Nevertheless, the Supreme Court noted that regardless of whether the defendant entered into a Federal Rule of Criminal Procedure 11(c)(1)(c) plea agreement, the district court had authority to entertain 18 U.S.C. § 3582(c)(2) motions when sentences were imposed in accordance with the guidelines [40-42]. In addition, the court held that Freeman's plea agreement was based on a sentencing guideline range, since the district court expressed its independent judgment that the sentence is suitable in accordance with that range [42]. Accordingly, the court reversed the appellate court's judgment and remanded the case.

\section{Singapore's Death Penalty for Drug Trafficking Offenses}

\subsection{The Singapore Legal System}

The Singapore judicial system has largely been influenced by the English judicial system because it originated as a British colony ${ }^{12}$. Singapore has the common law system of justice, which has its roots in the English common law tradition similar to neighboring countries (e.g., Malaysia, Brunei and Myanmar) [43]. Like the US and England, the Singaporean common law system is controlled by the legal principle of stare decisis [43]. Additionally, Singapore has enacted Muslim law, which is administered through the Syariah court [43]. Under the Administration of Muslim Law Act (AMLA), the Syariah court addresses certain legal issues (e.g., marriage and divorce) with respect to Muslim citizens [43].

In Singapore, the Constitution is the supreme statute, which provides a fundamental framework for three essential branches of government, including the executive, the legislative, as well as the judiciary branches ${ }^{13}$ [43]. Citizens' fundamental rights (e.g., freedom of speech and equal rights) are also protected by the Constitution; however, some individual rights have to be sacrificed to public order and security [43]. First, the executive branch, consisting of the president (elected by citizens), the

12 Singapore began as part of a British colony in 1819 when Sir Thomas Stamford Raffles of the British East India Company founded a British port on this country and became independent in 1965.

13 The Singaporean Constitution can only be amended by a referendum of two-thirds of the total number of the Parliament's members. 
cabinet (headed by the prime minister) and the attorney-general, is granted the power of veto to maintain the balance of power. Nevertheless, it should be noted that the definite separation of power between the executive and legislative branches are not established in Singapore, since members of the cabinet are chosen from the parliament's members [43]. In the legislative branch, the essential role of the parliament is to enact or amend laws. Further, under the Constitution, the Presidential Council for Minority Rights (PCMR) was also founded to deal with bills that create religious and racial biases [43].

Under the judiciary branch, the Singapore Supreme Court, consisting of the court of appeals and the high court, hears both civil and criminal cases [44]. The Constitutional Tribunal is the special court that hears questions regarding Constitutional matters [44]. Other courts include family courts, coroner's courts, juvenile courts, community courts and small claims tribunals. It should be noted that there is no special drug court in Singapore [44].

\subsection{Misuse of Drug Act (MDA)}

Amnesty International reports that Singapore is the country with the highest per capita execution rate in the world [45]. However, Singapore's Ministry of Home Affair indicated that the number of those executed for drug trafficking offenses is 110 persons during the last five years, as compared to 28 persons executed for non-drug offenses, including murder and arms-related offenses [12]. Thirty-seven out of the 138 persons executed were foreigners [12]. The international community considers mandatory sentences to reflect an arbitrary exercise of power, since the death penalty is triggered based on the amount of illicit drugs without considering any mitigating factors [11]. The Singapore Government responded to global condemnation over the imposition of the mandatory death sentence on drug trafficking and related offenses, arguing that Singapore is one of the safest countries in the world and that such sanctions are not irrational after weighing the right to life of a convicted offender against the right of victims and the right of the community as a whole ${ }^{14}$ [12]. The Singapore Government further pointed out that there is currently no consensus on the abolition of the death penalty and drug trafficking offenses are the most serious crimes in this country, which is located near the Golden Triangle, the world's second largest narcotic production area [12].

Under the Misuse of Drugs Act (MDA), illegal drugs in Singapore are scheduled into three levels, including class A drugs (e.g., amphetamine, cocaine, coca leaf, diamorphine), class B drugs (e.g., ketamine) and class C drugs (e.g., mephentermine) [46]. Table 2 presents the amount of each narcotic that triggers the mandatory death sentence under this act, regardless of examining any mitigating factors or case-specific circumstances. The Singapore Government states that this quantity standard is not unreasonable. For example, 15 grams of pure heroin is equivalent to 750 grams of normal heroin, which costs approximately US $\$ 100,000$ [12]. This is not a quantity intended for private use [12].

14 This argument is based on the 2003 Asian Intelligence Report of the Political and Economic Risks Consultancy (PERC), which indicates that the overall integrity and quality of the Singapore legal system was ranked on the top in Asia. 
Table 2. The quantity of illicit drugs that triggers the mandatory death penalty.

\begin{tabular}{cll}
\hline No. & Narcotic & Quantity \\
\hline 1. & Cocaine & 30 grams \\
2. & Pure Heroin (Diamorphine) & 15 grams \\
3. & Methamphetamine & 250 grams \\
4. & Marijuana & 500 grams \\
5. & Morphine & 30 grams \\
\hline
\end{tabular}

In addition, the Singapore Government also indicates that capital punishment will not be imposed on narcotic users; instead, they will be rehabilitated, so as to reintegrate them back into the community [12]. However, under Section 17 of MDA, for those who possess controlled substances over the limited level, courts will assume that the offender intends to use those drugs for purposes of trafficking [46]. Further, forfeiture of narcotic-related assets is also prescribed under MDA as a means to eradicate illicit drug-related enterprises in this country. In sum, the provision of MDA reflects how serious the Singapore Government perceives narcotic problems to be [46]. It is apparent that the Singapore Government considered drug trafficking offense as among the most serious crimes that threaten the country's security. Thus, for Singapore, mandatory death sentences for drug trafficking crimes are an appropriate method to deter drug crime [45].

\subsection{An Important Case: Yong Vui Kong v. Public Prosecutor (2010)}

On June 13, 2007, Yong Vui Kong, a 19-year-old Malaysian male, was arrested with 47 grams of heroin (not less than $42.27 \mathrm{~g}$ of diamorphine) [16,47]. In 2009, he was sentenced to death. He and his attorney, Mr. Madasamy Ravi, contended that the mandatory death penalty was unconstitutional on two grounds [47]. The first argument was that the mandatory death penalty deprived him of the fundamental norms of due process, since it failed to consider mitigating factors (individual circumstances) ([47], p. 38). The second issue raised was related to the equal protection argument, contending that the 15 grams differentia was arbitrary [16]. However, the Court of Appeals upheld the death penalty, ruling that the mandatory death penalty did not violate Article 9 (1) and Article 12 (1) of the Singaporean Constitution ([47], p. 36).

In term of case significance, this case is important, because Yong Vui Kong challenged the constitutional validity of the mandatory death sentence under the Misuse of Drugs Act. Since 1980, an appeal against the mandatory death penalty for drug offenses in Singapore was dismissed in the cases of Ong Ah Chuan (1981) and Nguyen Tuong Van (2004) [48,49]. Both the Ong Ah Chuan and Nguyen cases were unsuccessful in their challenges that the mandatory death penalty under the Misuse of Drugs Act infringed Article 9 (1) and 12 (1) of the Constitution [46,48,49]. Like preceding cases, Yong Vui Kong's arguments were also grounded in Article 9 (1) and 12 (1) of the Constitution [50].

Regarding the first argument, Yong Vui Kong contended that the nature of the mandatory death penalty was inhumane, since it violated provisions of the constitution, namely basic liberty of the person, equal protection and the vesting of judicial power. The mandatory death penalty was further inconsistent with customary international law norms prohibiting cruel and unusual punishment. However, the court argued that the defendant did not provide a sufficient rational justification as to why customary international law should be considered as a part of the law under Article 9 (1) of the 
Singaporean Constitution [50]. The court further held that "the court felt no compulsion to decide whether a sentence of the mandatory death penalty is an inhumane punishment, since the constitution does not express prohibition against inhumane punishment” ([16], p. 14).

For the equal protection argument, Yong Vui Kong argued that the 15 grams differentia was arbitrary and inconsistent with Article 12 (1) of the constitution [46,50]. The court employed a two-step reasonable classification standard used in the Nguyen case to test the validity of the act. This standard evaluates whether it is constitutional to sentence the classes of individuals trafficking in 15 grams or more of illicit drugs to higher penalty (death), as compared to those trafficking in less than 15 grams of illicit drug [47]. The court pointed out that the difference between 15 and 14.99 grams was reasonable [47].

However, in July 2012, the Singaporean government agreed to ratify changes to the mandatory death penalty for "those who only played the roles of courier and were not involved in any activities related to the supply or distribution of drugs” ([16], p. 29). The traffickers, if having satisfied this requirement, may apply to have the execution sentence changed to life imprisonment [16].

\section{Malaysia’s Death Penalty for Drug Trafficking Offenses}

\subsection{The Malaysia Legal System}

Like the US, Malaysia has two separate legal systems, namely (1) the federal legal system and (2) the state legal systems. Malaysia is a federation, consisting of 13 states and three federal territories. All 13 states have their own constitution, but the federal Constitution is the supreme law of the country and can only be amended by a referendum of two-thirds majority [51]. While federal laws are enacted by parliament, state laws are passed by state legislature. In Malaysia, the concept of federalism is also employed to maintain the separation of power [51]. That is, the frameworks of state and federal executive, legislative and judicial authorities are outlined in the federal Constitution. For instance, the legislative lists that federal and state legislative branches can enact are prescribed in the $9^{\text {th }}$ Schedule of the Constitution ${ }^{15}$ [52]. Like Singapore, Malaysia also has a separate set of laws and governances for the Muslim community. While personal law relating to Muslims and the establishment and regulation of Syariah Courts that deal only with Islamic law are under the state authorities, the federal legislature is empowered to make personal laws governing non-Muslims [52].

Judicial powers are vested in superior courts, consisting of the federal court, court of appeal, high court and the special court [53]. The Chief Justice of the federal court is the leader of the judiciary [53]. Other courts include session's court, magistrates' courts, Syariah courts, juvenile courts and the native courts [53]. In Malaysia, individual human rights, namely the right to life, freedom of speech, freedom of movement and the right to have equal education are guaranteed under the federal Constitution [54].

15 The state authority includes making personal laws governing Muslims and establishing Syariah courts the deal only with Islamic laws. 


\subsection{Dangerous Drugs Act (DDA) of 1952}

Like Singapore and other countries in Southeast Asia, the Malaysia Government determined narcotic (a local term called Dadah) problems as a major threat to the country's safety and security [55]. The National Anti-Drugs Agency (NADA), a subdivision of the Ministry of Home Affairs, reported that the main category of narcotics in Malaysia is heroin, followed by marijuana, morphine and amphetamine, respectively [55]. The number of persons arrested for drug-related offenses were 64,043 in 2008 and 75,623 in 2009, while 3,045 persons were those arrested under capital drug crimes [55]. Of the total offenders who were arrested for drug crimes, 969 prisoners were foreigners [55].

Narcotic offenses are commonly considered as the most serious crimes, since this country is usually used as a transit country for drug traffickers from the Golden Triangle to other destinations [55]. The seriousness of drug-related offenses is reflected in Malaysian drug legislation, which has extremely harsh punishment for narcotic traffickers. Specifically, six drug laws have been enacted to address the narcotic problems: (1) the Dangerous Drugs Act of 1952 (the major drug law), (2) the Poisons Act of 1952 (aiming at controlling substances, which are in the Poison List), (3) the Drug Dependents Act of 1983 (focusing on providing treatment and rehabilitation on drug abusers), (4) the Dangerous Drugs Act of 1985 (empowering law enforcement officers to detain a drug suspect without the courts' permission), (5) the Dangerous Drugs Act of 1988 (empowering law enforcement officers to forfeit narcotic-related assets) and (6) the National Anti-Drug Agency Act of 2004 (providing the establishment of the National Anti-Drug Agency (NADA)) [55].

This study focuses mainly on the Dangerous Drugs Act of 1952, since this is still the main drug statute covering all aspects of offenses, procedures and, more importantly, the mandatory death sentence for drug trafficking [55,56]. Specifically, under $\S 37$ of DDA, any possession of controlled substances over the limit prescribed under the Section is presumed to involve possession for the purpose of trafficking, which triggers the mandatory death sentence under §39 (B) [56]. Table 3 presents the quantity of narcotics that result in the presumption that trafficking is involved. It should be noted that unlike Singapore's drug law, the amount of heroin under Malaysian drug law is 15 grams of normal heroin, not pure heroin (diamorphine) [56]. Capital punishment was first used for drug trafficking in Malaysia in 1975 and became mandatory in 1983 [55].

Table 3. The quantity of narcotics that triggers the mandatory death penalty in Malaysia.

\begin{tabular}{lll}
\hline No. & Narcotic & Quantity \\
\hline 1. & Cocaine & 40 grams \\
2. & Heroin & 15 grams \\
3. & Methamphetamine & 50 grams \\
4. & Marijuana & 200 grams \\
5. & Morphine & 15 grams \\
\hline
\end{tabular}

\subsection{An Important Case: Malaysia v. Fazila Bee Abdul Kareem (2013)}

On February 13, 2009, Fazila Bee Abdul Kareem, a 62-year-old Indian woman, was arrested at the international arrival hall of the Kuala Lumpur International Airport for attempting to smuggle 2.9 kilograms of ketamine [57]. Fazila Bee testified that the reason that she had come to Malaysia was 
to look for a job [57]. She further argued that she received the bag that contained illegal drugs from a person in India who asked her to bring the bag to Malaysia [57]. However, the Malaysian High Court sentenced her to death, ruling that she failed to raise a reasonable doubt in this case [57]. The judge specifically pointed out that her testimony was unreasonable, since she entered the country with a tourist visa, not the working permit [57]. In addition, the judge noted that she was older than what she claimed [57]. Her appeal to the Court of Appeal was dismissed. Fazila Bee later filed an appeal to the Federal Court, which dismissed her appeal and affirmed the High Court's decision of her death sentence.

Regarding the case significance, this case affirmed the Malaysia Government's consideration of drug trafficking offense as one of the most serious crimes worthy of capital punishment. However, during the past few years, Malaysia seems to reflect the downward trends toward the use of the mandatory death penalty, noting that even though there were 860 prisoners on death row in 2012, the government is unlikely to execute death row prisoners. Specifically, the total number of execution in 2011 was zero [16]. In addition, the Malaysian government is currently considering replacing the mandatory death sentence with an alternative of 30 or more years in prison and also allowing judges to have discretionary power under the 1952 Dangerous Drugs Act [16,58]. Furthermore, in October 2012, the government began considering application of a moratorium on executions for those who are convicted of drug-related offenses in Malaysia, noting that approximately 450 death-row inmates were drug offenders [16].

\section{Indonesia's Death Penalty for Drug Trafficking Offenses}

\subsection{The Indonesia Legal System}

Unlike Singapore and Malaysia, the Indonesia legal system involves the civil law system, which is largely based on French and German legal traditions, as well as incorporating elements of Islamic law [59]. That is, Indonesia does not use the jury system; instead, decisions of both civil and criminal cases are made by a panel of judges, usually consisting of three judges [59]. Also, in Indonesia, the doctrine of stare decisis and the system of precedent is not applied to the judicial system ${ }^{16}$. Further, unlike the US, which uses an adversarial system, the Indonesian legal system employs an inquisitorial model of legal decision making in which judges play an important role in investigating the case, questioning witnesses, as well as making guilt/innocence and sentencing decisions [59]. In Indonesia, there are 250 courts of first instance (Pengadilan Negeri), 20 high courts or courts of appeal (Pengadilan Tinggi) and the Supreme Court (Mahkamah Agung), which is the highest court in Indonesia [59]. There are also many special courts in Indonesia, since in the civil law system, a judge often has to have specific knowledge in that case (e.g., military courts, religious courts, commercial courts and Constitutional court) [60].

Furthermore, the executive branch in Indonesia consists of the President, Vice-President and the cabinets. In Indonesia, the President has overwhelming power, since the government, as well as the armed forces, are under control of the President [61]. For the legislative branch, the House of People's Representatives (Dewan Perwakilan Rakyat (DPR)) has the major authority in the law-making process

16 That is, the current court's decisions will not be bound by the previous court's decision of the higher or the same level within the jurisdictions. Consequently, it is difficult to find a court's decision of the previous cases in Indonesia. 
and monitoring of the President and the cabinets [61]. In addition, the People's Consultative Assembly (Majelis Permusyawaratan Rakyat (MPR)) is the supreme institution empowered to amend the Constitution [62].

\subsection{Law No. 22 of 1997}

The objective of the Law No. 22 of 1997 was to eradicate illicit drug trafficking, to help drug abusers and to promote drug use for therapeutic and scientific purposes (see Article 3 of Law No. 22 of 1997) [63]. In Indonesia, narcotics are classified into three categories, namely category I (e.g., cocaine, marijuana, heroin and coca leaf), category II (e.g., morpheridine and racemethorphan) and category III (e.g., acetyldihydrocodeine, codeine and propiram) (see Article 2 of Law No. 22 of 1997) [63]. There is no mandatory capital punishment for those convicted of drug trafficking offenses; instead, the death penalty is available according to judicial discretion in sentencing as the maximum penalty (see Article 80 and 82 of Law No. 22 of 1997) [63]. That is, capital punishment for drug-related offenses is not triggered automatically based only on the quantity of illicit drugs, like in Malaysia and Singapore, but rather, the decision is based on case-specific circumstances and the judges' opinions. Table 4 presents the judicial discretion in sentencing for main narcotic types in Indonesia.

Table 4. Indonesian judicial discretion in sentencing for drug trafficking offenses.

\begin{tabular}{|c|c|c|}
\hline No. & Narcotic & Penalty \\
\hline 1. & Cocaine & $\begin{array}{l}\text { - the death penalty; or } \\
\text { - a life sentence; or } \\
\text { - imprisonment of no more than } 20 \text { years; and/or } \\
\text { - a fine of no more than IDR 1,000,000,000 (one billion rupiahs) }\end{array}$ \\
\hline 2. & Heroin & $\begin{array}{l}\text { - the death penalty; or } \\
\text { - a life sentence; or } \\
\text { - imprisonment of no more than } 20 \text { years; and/or } \\
\text { - a fine of no more than IDR 1,000,000,000 (one billion rupiahs) }{ }^{17}\end{array}$ \\
\hline 3. & Refined Opium & $\begin{array}{l}\text { - the death penalty; or } \\
\text { - a life sentence; or } \\
\text { - imprisonment of no more than } 20 \text { years; and/or } \\
\text { - a fine of no more than IDR 1,000,000,000 (one billion rupiahs) }\end{array}$ \\
\hline 4. & Marijuana & $\begin{array}{l}\text { - the death penalty; or } \\
\text { - a life sentence; or } \\
\text { - imprisonment of no more than } 20 \text { years; and/or } \\
\text { - a fine of no more than IDR 1,000,000,000 (one billion rupiahs) }\end{array}$ \\
\hline 5. & Methamphetamine & $\begin{array}{l}\text { - Law No. } 22 \text { of } 1997 \text { does not specifically indicate the penalty for } \\
\text { trafficking in methamphetamine }\end{array}$ \\
\hline
\end{tabular}

It should further be noted that in Indonesia, the death penalty cannot be imposed on illicit drug users; instead, medical and social rehabilitation is to be used as the main method of punishment when courts find an individual guilty of abusing narcotics (Articles 47 and 48 of Law No. 22 of 1997) [63].

17 One dollar is equal to approximately 9019 Rupiahs. 


\subsection{An Important Case: The Bali Nine Case}

In April 2005, the Australia Federal Police (AFP) reported to the Indonesian National Police (INP) that there were a group of Australians planning to smuggle a large quantity of heroin to Bali [10]. As a result, on April 17, 2005, nine Australians were arrested by the INP in Denpasar for attempting to smuggle 8,300 grams of heroin from Bali to Australia. All of them were charged with violation of Articles 82(1)(a) ${ }^{18}$ and 78(1)(b) ${ }^{19}$ of Law No. 22 of 1997 [64].

During the trial at Denpasar's district court, two of the nine Australians, Andrew Chan and Myuran Sukumaran, were sentenced to death, while the other seven were sentenced to life imprisonment [10]. The high court of Bali affirmed the death sentence on Chan and Sukumaran; however, for five of the seven offenders, the court reduced the sentences from life imprisonment to twenty years of imprisonment [10]. The convicted offenders then filed petitions to the Supreme Court, which granted appeals. The Supreme Court (Mahkamah Agung) reversed the earlier decisions of Bali's high court and imposed death sentences on six of the nine Australians (Chan, Sukumaran, Scott Rush, Tan Duc Thanh Nguyen, Si Yi Chen and Matthew Norman), life sentences on the two Australians (Michael Czugaj and Martin Stephens) and a sentence of a twenty-year prison term to Renae Lawrence [65]. However, on March, 2008, the Supreme Court reduced the death sentences of three offenders (Nguyen, Chen and Norman) to life imprisonment without official announcement. In August, 2010, Rush chose to challenge his death sentence to the Supreme Court through the process of a judicial review (a peninjauankembali (PK)). As a result, the court later commuted that death penalty to life in prison. However, the appeals made by Chan and Sukumaran to challenging the constitutional validity of the death sentence were rejected. On February 14, 2006, Sukumaran was executed by firing squad. Chan is now in prison waiting for execution.

This case is significant since the convicted offenders challenged the constitutional validity of Law No. 22 of 1997 by filing an appeal to the Indonesian Constitutional Court (the Mahkamah Konstitusi Republik Indonesia (MKRI)). They specifically claimed that the provision of Law No. 22 of 1997 is inconsistent with the Articles 28A and 28I (1) of the 1945 Indonesian Constitution [59], as well as Article 6 of the International Covenant on Civil and Political Right (ICCPR), which is an international human rights law. However, the MKRI Court rejected their appeal on the grounds that foreigners cannot challenge the domestic Constitution and the right to life under the Constitution can be restricted by provisions of Indonesian statutes [66]. After the failure of challenging the validity of the death sentence under Law No. 22 of 1997, those who were issued death sentences took another method of appeal involving the process of judicial review by the Supreme Court (a peninjauankembali (PK)), for their appeals [59,61].

In addition, the Bali Nine case is also essential, since considerable conflict between the Indonesian and Australian Governments was created as a result of the court's decision in this case. One important

18 Law No. 22 of 1997 (stating that "import, exports, offers for sale, distributes, sells, buys, delivers, acts as broker or exchanges narcotics Category I, shall be punished with the death penalty, or life sentence, or imprisonment of not more than 20 years, and a fine of not more than IDR 1,000,000,000 rupiahs.”) [63].

19 Law No. 22 of 1997 (stating that to "possess, keep in stock, or control narcotics Group 1, other than in the form of plants, shall be punished with an imprisonment of not more than 10 years and a fine of not more than IDR 500,000,000.00 rupiahs.”) [63]. 
reason for this conflict is that the Indonesian President, Susilo Bambang Yudhoyono, rejected personal clemency from Kevin Rudd, the Australian Prime Minister [67]. President Yudhoyono further rejected similar diplomatic efforts from Australia's Foreign Minister and the Australian Embassy to avoid capital punishment in this case in December, 2005 [10]. This case illustrates the Indonesian Government's determination when sanctioning drug crimes as the most essential threat to national security. The President's statement during the testimony at the Constitutional Court affirmed this, indicating that drug trafficking is a very serious crime in this country in which the death penalty is proportionate to the gravity of the offense ([10], p. 528). Consequently, even though four of the six offenders who were sentenced to death by the Supreme Court received a reduction in their sentences, the other two offenders (Chan and Sukumaran) failed to receive a similar reduction.

\section{Thai’s Death Penalty for Drug Trafficking Offenses}

\subsection{The Thai Legal System}

The Thai legal system follows the civil law (code) system influenced by the common law, since most contents of the written legislation are impacted by the legal system of common law countries (e.g., England) [68,69]. Thailand has no jury system, and the system of precedents is not applied to the legal system [70]. The Constitution is the supreme law of the country, outlining three essential functions: (1) the executive, (2) the legislative and (3) the judicial branches. The King is separate from all three branches and serves as the symbolic chief of the country ${ }^{20}$ [68]. The executive branch consists of the prime minister and the cabinets. The prime minister is the leader of the government, who is elected from the members of the House of Representatives and cabinets [68,70]. The legislative branch, including 200 members of senates and 500 members of the House of Representatives, has the main authority in the law-making process [68,70]. Lastly, the judicial branch is headed by the chief judge of the Supreme Court. The hierarchy of the Thai judicial system has three levels, namely (1) courts of first instance, (2) courts of appeal and (3) the Supreme Court (Sandika). The Supreme Court is the highest court and has jurisdiction covering all provinces of Thailand. Courts of first instance include general courts, juvenile and family courts, as well as specialized courts (e.g., the central labor court, the central tax court, the central bankruptcy court and the central intellectual property and international trade court) [68].

\subsection{Narcotics Act, B.E. 2522 (1979)}

Table 5 presents the judicial discretion in sentencing for main narcotic types in Thailand. Illicit drugs under the Thai Narcotics Act are divided into five categories: Category I (dangerous drugs, such as heroin and methamphetamine), Category II (e.g., morphine, cocaine and medicinal opium), Category III (e.g., those narcotics in the form of medicinal formula), Category IV (e.g., acetic anhydride, acetyl chloride and ingredients of narcotics categories I and II) and Category V (e.g., marijuana) (see Section 7 of Narcotics Act, B.E. 2522) [71]. It should be noted that methamphetamine

20 Now, the King of Thailand is the King Bhumibol Adulyadej (King Rama IX). 
is categorized under narcotics Category I, since the U.N. reported that Thailand has the highest rate of methamphetamine abuse (locally called Yaba) in the world [2].

In addition, like Singapore and Malaysia, presumption concerning possession of narcotics for the purpose of trafficking is applied to an offender if the quantity of illicit drugs possessed is over the limits prescribed under the Narcotics Act, B.E. 2522 [71]. For instance, possession of over 20 grams of Category I narcotics is assumed to involve possession for the purpose of trafficking (Section 15 of Narcotics Act, B.E. 2522 at para 2), and the penalty for that charge is enhanced (Section 67 of Narcotics Act, B.E. 2522) [71]. By contrast, it is important to point out that an illicit-drug addict is considered a patient, not an offender; thus, for a narcotic abuser, courts commonly order him or her to undergo rehabilitation (Narcotics Addict Rehabilitation Act, B.E. 2545 (2002)) [72]. Moreover, a drug trafficking offender in Thailand has to face asset forfeiture under Acts of the Measures for the Suppression of Offenders in an Offense Relating to Narcotics, B.E. 2534 (1991) [73].

Table 5. Thai judicial discretion in sentencing for drug trafficking offenses ${ }^{21}$.

\begin{tabular}{|c|c|c|c|}
\hline No. & Narcotic & Quantity & Penalty \\
\hline 1. & Cocaine (Category II) & 100 grams & $\begin{array}{l}\text { - imprisonment from } 1 \text { to } 10 \text { years; and/or } \\
\text { - a fine of between 10,000 and 100,000 baht }\end{array}$ \\
\hline 2. & Heroin (Category I) & 100 grams & $\begin{array}{l}\text { - the death penalty; or } \\
\text { - a life sentence }\end{array}$ \\
\hline 3. & $\begin{array}{l}\text { Methamphetamine } \\
\text { (Category I) }\end{array}$ & 100 grams & $\begin{array}{l}\text { - the death penalty; or } \\
\text { - a life sentence }\end{array}$ \\
\hline 4. & Marijuana (Category V) & 10 kilograms & $\begin{array}{l}\text { - imprisonment from } 2 \text { to } 5 \text { years; and/or } \\
\text { - a fine of between 20,000 and 150,000 baht }\end{array}$ \\
\hline 5. & Morphine (Category II) & 100 grams & $\begin{array}{l}\text { - imprisonment from } 5 \text { years to life sentence; } \\
\text { and/or } \\
\text { - a fine of no more than } 50,000 \text { baht }\end{array}$ \\
\hline
\end{tabular}

9.3. An Important Case: Thailand v. Sefu (2002)

On December 17, 1998, Muhammed Sefu, an Ethiopian, was arrested at the Thai International Airport for attempting to smuggle a packet of heroin (7,818.8 grams) from Thailand to Addis Ababa, Ethiopia. An airport police officer found a packet of heroin concealed in his notebook computer during check-in at the passport control and charged him with violations of $\S 15, \S 65$ and $\S 66$ of the Narcotics Act, B.E. 2522. The court of first instance sentenced him to death, ruling that the death penalty was appropriate in this case, since the amount of narcotics that a defendant tried to smuggle was very large and there were no mitigating factors for the defendant. The court further stated that drug trafficking is a very heinous crime that has devastating social and economic effects on Thailand and the global community as a whole, and it also poses a major threat to the national security. Sefu appealed the guilty verdict based on the fact that he had not passed the passport control at the airport yet, so he did not violate $\S 65$ of Narcotics Act, which prohibit exporting narcotics. The appeal court affirmed the lower court's decision, which sentenced him to death. Then, Sefu filed an appeal to the Supreme Court, which, later, granted his appeal and commuted his death sentence to life imprisonment.

21 One dollar is equal to 31 baht. 
Regarding the case significance, the Thai Supreme Court rarely grants an appeal for cases related to drug trafficking; however, in 2003, the Court granted an appeal in the Sefu case, holding that the defendant already violated the $\S 65$ and $\S 66$ of the Narcotics Act, B.E. 2552, prohibiting the import or export of the Category I narcotics, even though the defendant had not yet passed the check-in process at the passport control of the Bangkok International Airport. Nevertheless, the Court reversed the judgment of the Court of Appeals and commuted the death penalty to life imprisonment, because the Court determined that the imposition of the death penalty was disproportionate to the gravity of the offense in this case.

It is crucial to point out that this Court's decision is consistent with the Thai governmental policy endorsing a human rights plan aiming to replace the death penalty with a sentence of life imprisonment [74]. Even though there are a large number of the capital narcotics offenders who are sentenced to death each year, to date, modern Thai courts rarely carry out the executions in practice $^{22}[15,17,74]$. Further, in Thailand, a death-row inmate can file a royal-pardon petition to the King, who is likely to grant a clemency plea on special events, such as the King's birthday, as well as the anniversary of his ascension to the throne [74]. However, since drug-related crimes tend to be considered among the most serious crimes in Thailand, a royal-pardon petition for an offender convicted of a drug-related offense tends to be rejected [75].

\section{Conclusions}

\subsection{Conclusions and Discussion}

The comparison of the narcotics legislation and important legal cases across five countries (the US, Singapore, Malaysia, Indonesia and Thailand) is presented in Tables 6-8. Southeast Asian countries perceive drug trafficking as the most serious issue, since the Golden Triangle, the world's second largest market of narcotics, is located in this region. Accordingly, there is no surprise that the way the governments in this region deal with drug problems is gaining more attention from the international community. The drug trafficking issue in Southeast Asia is being addressed at three levels: (1) the international cooperation through the treaty regime; (2) the United States' cooperation; and (3) the ASEAN drug control system. This study compared and contrasted domestic narcotics laws, as well as essential capital drug-related cases, in four Southeast Asian countries (Singapore, Malaysia, Indonesia and Thailand) to that of the United States' federal laws. In all instances, this study demonstrates that capital punishment is a disproportionate punishment to the gravity of drug-related offenses on the following grounds: (1) the consideration of drug trafficking as among the most serious crimes is questionable; (2) the use of the death penalty for drug offenses is an arbitrary exercise; and (3) there is a greater risk for wrongful conviction when using a mandatory death sentence.

First, despite the lack of a definitive statement on the term of the most serious crimes under Article 6 (2) of ICCPR, there is an implicit consensus that the most serious crime should be interpreted as life-threatening offenses or crimes that result in the loss of life (e.g., homicide). That is, many UN agencies (the UN Human Rights Committee, the UN General Assembly, the Economic and Social

22 Thai Human Rights Organization specifically indicated that 333 of 708 persons are sentenced to death for drug-related crimes in 2010; however, courts are reluctant to execute those death-row inmates in practice. 
Council of the UN, UN Special Rapporteur and the UN Secretary-General) have an agreement regarding the meaning of the term most serious crimes. They are all likely to limit the use of the death penalty to include only intentional crimes with fatal outcomes [8]. Second, it is apparent that the use of the death penalty for drug trafficking in this region is likely to be an arbitrary exercise, which is prohibited under the international human rights law (ICCPR). This arbitrary nature is demonstrated when crimes resulting in the death penalty in one country are only minor offenses in neighboring countries [8]. For instance, the amount of heroin that triggers the death penalty in Singapore is 15 grams of diamorphine (equivalent to 750 grams of normal heroin) as opposed to 15 grams of normal heroin in Malaysia. Also, methamphetamine is classified as the most serious narcotic under Category I in Thailand, while it is not specifically stated in Indonesian narcotics law.

Furthermore, there is a greater risk in wrongful convictions in countries using a mandatory death penalty based only on the quantity of narcotics involved in the case (e.g., Singapore and Malaysia). That is, for these two countries, case-specific circumstances and any mitigating factors would be ignored simply because a drug offender possessed illicit drugs over the limit prescribed under the law. As established in the Yong Vui Kong case in Singapore, the Supreme Court refused to consider case-specific circumstances or any mitigating factors (e.g., age) when reviewing that case. It cannot be denied that not only drug traffickers, but also drug addicts have a greater risk of being executed, since they will be presumed to be trafficking if they possess narcotics over the limits prescribed under the narcotics law [1].

Fortunately, four Southeast Asian countries in this study (Singapore, Malaysia, Thailand and Indonesia) are now realizing this issue and have become reluctant to carry out executions of drug offenders, even though there are a large number of inmates sentenced to death for drug offenses annually. For Singapore, the number of executions for drug offenses has declined significantly in recent years. The total number of executions for drug offenses in 2011 was two [16]. In addition, the Singaporean government's use of capital punishment has recently become more transparent since the government started, including the number of executions it carries out in its annual report. In addition, in July 2012, the Singaporean government agreed to ratify changes changing mandatory death penalty sentences to life imprisonment for individuals who only played the role of courier and were not involved in any activities related to the supply or distribution of drugs [16]. Like Singapore, even though the Malaysian government is so serious about drug offenses and employs the mandatory death penalty to deter such crimes as established in the Fazila Bee Abdul Kareem case, the government seems to be involved in a downward trend in the use of such cases and appears to be involved in more subtle movement toward the abolition of the capital punishment. The number of executions in Malaysia was reduced dramatically to 44 in 2012 (from January to August). Also, the Malaysian government is currently considering replacing the mandatory death penalty with an alternative of 30 or more years in prison and is also considering allowing judges to have discretionary power in such sentence deliberations. Specifically, in October 2012, the government is considering applying a moratorium on executions for those convicted in Malaysia. 
Table 6. Comparison of narcotics legislation across five countries: the US, Singapore, Malaysia, Indonesia and Thailand.

\begin{tabular}{|c|c|c|c|c|c|c|c|}
\hline Country & $\begin{array}{l}\text { Having the Death } \\
\text { Penalty for Drug- } \\
\text { related Offenses }\end{array}$ & $\begin{array}{l}\text { Having } \\
\text { Mandatory } \\
\text { Death Penalty }\end{array}$ & $\begin{array}{l}\text { The quantity of } \\
\text { narcotics affecting } \\
\text { judicial decision in } \\
\text { sentencing }\end{array}$ & $\begin{array}{l}\text { Drug } \\
\text { Scheduling } \\
\text { System }\end{array}$ & $\begin{array}{l}\text { The presumption of } \\
\text { possession for the } \\
\text { purpose of trafficking }\end{array}$ & $\begin{array}{l}\text { The consideration } \\
\text { of a drug addict as } \\
\text { a patient }\end{array}$ & Asset Forfeiture \\
\hline \multirow[t]{2}{*}{ The US } & $\checkmark$ & $x$ & $\checkmark$ & $\checkmark$ & $x$ & $\sqrt{ }$ & $\checkmark$ \\
\hline & $\begin{array}{l}\text { (the Federal Death Penalty } \\
\text { Act } 18 \text { U.S.C. 3591(b)) }\end{array}$ & & $\begin{array}{l}\text { (punishment depending on the } \\
\text { type and quantity of } \\
\text { substances in which an } \\
\text { offender engaged in) }\end{array}$ & (5 schedules) & & (21 U.S.C. Ch.16) & (21 U.S.C. §848, §853) \\
\hline \multirow[t]{2}{*}{ Singapore } & $\checkmark$ & $\checkmark$ & $\checkmark$ & $\checkmark$ & $\checkmark$ & $\checkmark$ & $\checkmark$ \\
\hline & $\begin{array}{l}\text { (possessing narcotics over } \\
\text { the limit prescribed under } \\
\text { MDA) }\end{array}$ & $\begin{array}{c}\text { (based on the quantity } \\
\text { of narcotics) }\end{array}$ & $\begin{array}{l}\text { (the quantity of illicit drugs } \\
\text { triggering the mandatory } \\
\text { death penalty) }\end{array}$ & ( 3 classes) & $\begin{array}{l}\text { (Article } 17 \text { of the Misuse of Drugs } \\
\text { Act of 1973) }\end{array}$ & $\begin{array}{c}\text { (Article } 37 \text { of the Misuse of } \\
\text { Drugs Act of 1973) }\end{array}$ & $\begin{array}{c}\text { (Article } 28 \text { of the } \\
\text { Misuse of Drugs Act of } \\
\text { 1973) }\end{array}$ \\
\hline \multirow[t]{2}{*}{ Malaysia } & $\checkmark$ & $\checkmark$ & $\checkmark$ & $\checkmark$ & $\checkmark$ & $\checkmark$ & $\checkmark$ \\
\hline & $\begin{array}{l}\text { (possessing narcotics over } \\
\text { the limit prescribed under } \\
\text { DDA) }\end{array}$ & $\begin{array}{l}\text { (based on the quantity } \\
\text { of narcotics) }\end{array}$ & $\begin{array}{l}\text { (the quantity of illicit drugs } \\
\text { triggering the mandatory } \\
\text { death penalty) }\end{array}$ & $\begin{array}{l}\text { ( } 5 \text { parts of the } \\
\text { first schedule) }\end{array}$ & $\begin{array}{l}\text { (Article } 37 \text { of the Dangerous Drugs } \\
\text { Act of 1952) }\end{array}$ & $\begin{array}{l}\text { [under different law (the } \\
\text { Drug Dependents Act of } \\
\text { 1983)] }\end{array}$ & $\begin{array}{c}\text { [under different law (the } \\
\text { Dangerous Drugs Act of } \\
\text { 1988] }\end{array}$ \\
\hline Indonesia & $\begin{array}{c}\checkmark \\
\text { (import, export, offer for } \\
\text { sale, distribute, sell, buy, } \\
\text { deliver, act as broker or } \\
\text { exchange category I } \\
\text { narcotics) }\end{array}$ & $x$ & $\begin{array}{c}\checkmark \\
\text { (a level of penalties } \\
\text { depending on judges’ } \\
\text { opinions) }\end{array}$ & $\begin{array}{c}\checkmark \\
\text { (3 categories) }\end{array}$ & $x$ & $\begin{array}{c}\checkmark \\
\text { (Article } 47 \text { of Law No. } 22 \text { of } \\
\text { 1997) }\end{array}$ & $x$ \\
\hline \multirow[t]{2}{*}{ Thailand } & $\checkmark$ & $x$ & $\checkmark$ & $\checkmark$ & $\checkmark$ & $\checkmark$ & $\checkmark$ \\
\hline & $\begin{array}{l}\text { (import, export, or possess } \\
\text { the narcotics of category I } \\
\text { (over } 100 \text { grams) for the } \\
\text { purpose of disposal) }\end{array}$ & & $\begin{array}{l}\text { (the higher the amount of } \\
\text { narcotics an offender } \\
\text { involved in, the more } \\
\text { punishment he or she } \\
\text { receives) }\end{array}$ & (5 categories) & $\begin{array}{c}\text { (Articles 15, 17, and } 26 \text { of } \\
\text { Narcotics Act B.E. 2552) }\end{array}$ & $\begin{array}{c}\text { [under different law } \\
\text { (Narcotics Addict } \\
\text { Rehabilitation Act B.E. } \\
2545 \text { (2002)] }\end{array}$ & $\begin{array}{l}\text { [under a different law } \\
\text { (Acts of the Measures } \\
\text { for the Suppression of } \\
\text { Offenders in an Offense } \\
\text { Relating to Narcotics, } \\
\text { B.E. } 2534 \text { (1991)] }\end{array}$ \\
\hline
\end{tabular}


Table 7. Comparison of important drug trafficking cases across five countries: the US, Singapore, Malaysia, Indonesia and Thailand.

\begin{tabular}{|c|c|c|c|c|c|c|c|}
\hline Country & Case & $\begin{array}{l}\text { Date of } \\
\text { arrest }\end{array}$ & $\begin{array}{l}\text { Date of } \\
\text { execution }\end{array}$ & Charge & Court decision & Reason & Case significance \\
\hline The US & $\begin{array}{l}\text { Freeman } v . \\
\text { United States }\end{array}$ & $01 / 2005$ & - & $\begin{array}{l}\text { One count of crack } \\
\text { cocaine possession, } \\
\text { two counts of weapon } \\
\text { possession and one } \\
\text { count of marijuana } \\
\text { possession }\end{array}$ & $\begin{array}{l}\text { A defendant is } \\
\text { eligible for a } \\
\text { sentence } \\
\text { reduction under } \\
18 \text { U.S.C. § } 3582 \\
\text { (c)(2) }\end{array}$ & $\begin{array}{l}\text { Freeman’s plea } \\
\text { agreement was based } \\
\text { on a sentencing } \\
\text { guidelines range }\end{array}$ & $\begin{array}{l}\text { This case is related to } \\
\text { fairness in sentencing } \\
\text { guidelines for } \\
\text { individuals convicted of } \\
\text { drug offenses }\end{array}$ \\
\hline Singapore & $\begin{array}{l}\text { Yong Vui Kong } \\
\text { v. Public } \\
\text { Prosecutor }\end{array}$ & 06/13/2007 & $\begin{array}{l}\text { Yong Vui } \\
\text { Kong was } \\
\text { sentenced to } \\
\text { death, } \\
\text { but not } \\
\text { executed yet }\end{array}$ & $\begin{array}{l}\text { Possessing } 47 \mathrm{~g} \text { of } \\
\text { heroin (not less than } \\
42.27 \mathrm{~g} \text { of } \\
\text { diamorphine) }\end{array}$ & $\begin{array}{l}\text { Guilty and } \\
\text { sentenced } \\
\text { to death }\end{array}$ & $\begin{array}{l}\text { The defendant did not } \\
\text { provide a justification } \\
\text { why customary } \\
\text { international law should } \\
\text { be considered as a part of } \\
\text { Article } 9 \text { (1) of the } \\
\text { Constitution; } \\
\text { the difference between } 15 \\
\text { g and } 14.99 \mathrm{~g} \text { was } \\
\text { reasonable }\end{array}$ & $\begin{array}{l}\text { A defendant challenged } \\
\text { the constitutional validity } \\
\text { of the mandatory death } \\
\text { sentence under the } \\
\text { Misuse of Drugs Act }\end{array}$ \\
\hline Malaysia & $\begin{array}{l}\text { MALAYSIA v. } \\
\text { Fazila Bee } \\
\text { Abdul Kareem }\end{array}$ & 02/13/2009 & $\begin{array}{l}\text { Fazila Bee was } \\
\text { sentenced to } \\
\text { death, but not } \\
\text { executed yet }\end{array}$ & $\begin{array}{l}\text { Attempting to } \\
\text { smuggle } 2.9 \mathrm{~kg} \text { of } \\
\text { ketamine }\end{array}$ & $\begin{array}{l}\text { Guilty and } \\
\text { sentenced } \\
\text { to death }\end{array}$ & $\begin{array}{l}\text { The quantity of ketamine } \\
\text { that the convicted } \\
\text { offenders possessed } \\
\text { exceeded the } 15 \mathrm{~g} \text { limit, } \\
\text { which triggered the } \\
\text { mandatory } \\
\text { death sentence. }\end{array}$ & $\begin{array}{l}\text { This case affirmed the } \\
\text { government's } \\
\text { considerations of drug } \\
\text { offenses as the most } \\
\text { serious crimes }\end{array}$ \\
\hline
\end{tabular}


Table 7. Cont.

\begin{tabular}{|c|c|c|c|c|c|c|c|}
\hline Country & Case & Date of arrest & $\begin{array}{l}\text { Date of } \\
\text { execution }\end{array}$ & Charge & Court decision & Reason & Case significance \\
\hline Indonesia & $\begin{array}{l}\text { Indonesia v. Nine } \\
\text { Australians }\end{array}$ & $04 / 17 / 2005$ & $\begin{array}{l}02 / 17 / 2006 \\
\text { (Myuran } \\
\text { Sukumaran) }\end{array}$ & $\begin{array}{l}\text { Attempting to } \\
\text { smuggle } 8,300 \\
\text { grams of heroin } \\
\text { from Bali } \\
\text { to Australia }\end{array}$ & $\begin{array}{l}\text { The court found all } \\
\text { offenders guilty and } \\
\text { imposed the death } \\
\text { penalty on Sukumaran } \\
\text { and Chan; a } 20 \text { year } \\
\text { prison term to } \\
\text { Lawrence; and life } \\
\text { imprisonment on the } \\
\text { other six offenders. }\end{array}$ & $\begin{array}{l}\text { Drug-related } \\
\text { crime is the most } \\
\text { serious crime and } \\
\text { the right to life } \\
\text { under the } \\
\text { Constitution can } \\
\text { be restricted by } \\
\text { Indonesia laws }\end{array}$ & $\begin{array}{l}\text { Defendants } \\
\text { challenged the } \\
\text { Constitutional } \\
\text { validity of the death } \\
\text { sentence under Law } \\
\text { No. } 22 \text { of } 1997\end{array}$ \\
\hline Thailand & Thailand v. Safu & 12/17/1998 & $\begin{array}{l}\text { The death } \\
\text { penalty was } \\
\text { commuted to } \\
\text { life } \\
\text { imprisonment }\end{array}$ & $\begin{array}{l}\text { Attempting to } \\
\text { export Category I } \\
\text { narcotics for the } \\
\text { purpose } \\
\text { of disposal }\end{array}$ & $\begin{array}{l}\text { The Court found him } \\
\text { guilty, but commuted } \\
\text { the death sentence to } \\
\text { life imprisonment }\end{array}$ & $\begin{array}{l}\text { Even though it is } \\
\text { clear that he } \\
\text { violated the } \\
\text { narcotics law, the } \\
\text { death penalty is a } \\
\text { disproportionate } \\
\text { response to the } \\
\text { gravity of the } \\
\text { offense in } \\
\text { this case }\end{array}$ & $\begin{array}{l}\text { The Thai Supreme } \\
\text { Court rarely granted } \\
\text { an appeal for those } \\
\text { convicted of } \\
\text { drug-related crimes; } \\
\text { however, this Court } \\
\text { granted an appeal } \\
\text { and reversed the } \\
\text { judgment of the } \\
\text { court of appeal in } \\
\text { this case }\end{array}$ \\
\hline
\end{tabular}


Table 8. Similarities and differences with regard to narcotics laws across five countries.

\begin{tabular}{|c|c|c|c|}
\hline No. & Variable & Similarities (YES) & Differences (NO) \\
\hline 1. & $\begin{array}{l}\text { The death sentence is allowed for } \\
\text { drug-related offenses }\end{array}$ & $\begin{array}{l}\text { The US, Singapore, Malaysia, } \\
\text { Indonesia and Thailand }\end{array}$ & - \\
\hline 2. & $\begin{array}{l}\text { The amount of narcotics has a } \\
\text { significant impact on judicial decision } \\
\text { in sentencing }\end{array}$ & $\begin{array}{l}\text { The US, Singapore, Malaysia, } \\
\text { Indonesia and Thailand }\end{array}$ & - \\
\hline 3. & $\begin{array}{l}\text { Possession of controlled substances } \\
\text { over the limits prescribed in laws is } \\
\text { assumed as possession for the purpose } \\
\text { of trafficking }\end{array}$ & $\begin{array}{l}\text { Singapore, Malaysia } \\
\text { and Thailand }\end{array}$ & The US and Indonesia \\
\hline 4. & $\begin{array}{l}\text { The death penalty can be imposed on } \\
\text { offenders convicted only of } \\
\text { drug offenses }\end{array}$ & $\begin{array}{l}\text { The US, Singapore, Malaysia, } \\
\text { Indonesia and Thailand }\end{array}$ & - \\
\hline 5. & $\begin{array}{l}\text { Drug addicts are considered } \\
\text { as patients }\end{array}$ & $\begin{array}{l}\text { The US, Singapore, Malaysia, } \\
\text { Indonesia and Thailand }\end{array}$ & - \\
\hline 6. & $\begin{array}{l}\text { The drug scheduling system is } \\
\text { clarified under narcotics laws }\end{array}$ & $\begin{array}{l}\text { The US, Singapore, Malaysia, } \\
\text { Indonesia and Thailand }\end{array}$ & - \\
\hline 7. & $\begin{array}{l}\text { Drug trafficking and related offenses } \\
\text { are determined the most } \\
\text { serious crimes }\end{array}$ & $\begin{array}{l}\text { Singapore, Malaysia, Indonesia } \\
\text { and Thailand }\end{array}$ & $\begin{array}{l}\text { The US (considering drug } \\
\text { crime as serious, but not the } \\
\text { most serious crime, since the } \\
\text { death penalty is highly } \\
\text { unlikely to be imposed on an } \\
\text { offender convicted solely of } \\
\text { drug offenses) }\end{array}$ \\
\hline 8. & $\begin{array}{l}\text { Narcotics laws are criticized as } \\
\text { violating the International Human } \\
\text { Rights Law (ICCPR) }\end{array}$ & $\begin{array}{l}\text { Singapore, Malaysia, Indonesia } \\
\text { and Thailand }\end{array}$ & The US \\
\hline 9. & $\begin{array}{l}\text { Asset forfeiture is used as a means to } \\
\text { eradicate drug trafficking enterprise. }\end{array}$ & $\begin{array}{l}\text { The US, Singapore, Malaysia } \\
\text { and Thailand }\end{array}$ & Indonesia \\
\hline 10. & $\begin{array}{l}\text { Based on important cases described in } \\
\text { this study, a defendant was sentenced } \\
\text { to death }\end{array}$ & $\begin{array}{l}\text { Singapore, Malaysia } \\
\text { and Indonesia }\end{array}$ & The US and Thailand \\
\hline 11. & $\begin{array}{l}\text { Based on important cases described in } \\
\text { this study, a defendant challenged the } \\
\text { constitutional validity of capital } \\
\text { punishment in narcotics law }\end{array}$ & Singapore and Indonesia & $\begin{array}{l}\text { The US, Malaysia } \\
\text { and Thailand }\end{array}$ \\
\hline
\end{tabular}

In Indonesia, even though a majority of the death-row prisoners are sentenced for drug offenses, the government expresses discomfort with the use of capital punishment and has rarely conducted executions for drug-related offenses during the past few years [16]. The last execution for drug offenses in Indonesia occurred in 2008. Also, in 2011, the President of Indonesia, Susilo Bambang Yudhoyono, officially formed a task force to provide legal assistance to Indonesian citizens who are convicted of capital charges in foreign countries [16]. Like Singapore and Malaysia, the Thai 
government is considering replacing capital punishment with life imprisonment without parole in the human rights plan the government has been enacting from 2009 to 2013 [74]. The last execution for drug offenses in Thailand took place in 2009 [15,16]. Furthermore, as a result of the legal analysis of this study, it should be pointed out that there is international consensus across these four Southeast Asian countries that a drug addict is determined to be a patient, not an offender.

In sum, this paper suggests that international drug control agencies should recommend effective ways to confront the drug problem instead of using the death penalty in Southeast Asian nations and to criticize or to sanction those countries who ignore such recommendations.

\subsection{Unresolved Issues and Trends}

For future research, even though death penalty statistics in Vietnam and China are state secrets, it would be worthwhile to examine the use of the death penalty for drug crimes in these two authoritarian countries, because there are claims indicating that these two countries have extremely high execution rates for drug-related crimes [1,8]. Amnesty International estimated that in China, approximately 1,000 people were executed for drug-related offenses in 1989 alone. They further claim that the government usually has conducted mass executions for those convicted of drug offenses on the UN International Day against Drug Abuse and Illicit Trafficking (June 26 ${ }^{\text {th }}$ ) since 1991 [1]. Specifically, Amnesty International noted that seventy-six offenders for drug offenses were publicly executed during a seven-day period around June 26, 2001, and sixty-four public executions in 2002 [76]. International Harm Reduction Association (IHRA) similarly reported that China has used June 26 as an occasion for mass public trials and executions of drug offenders [76]. In addition, approximately 100 death-row inmates for drug offenses are executed in Vietnam annually [17].

Assessing the use of capital punishment for drug-related offenders in Middle Eastern nations in a comparative perspective is also recommended, since Middle Eastern countries, namely Iran, Bahrain, Jordan, Kuwait, Saudi Arabia and the United Arab Emirates, still use the death penalty for drug offenders. Amnesty International specifically reports that Iran has the highest rate of execution for drug offenses ${ }^{23}[1]$ as compared to other nations, since a mandatory death sentence is employed in this country $^{24}$ [8]. Similarly, Jordan and the United Arab Emirates also use a mandatory death penalty for drug offenders who are government officers or repeat drug offenders, respectively $[1,8]$. In addition, Saudi Arabia was highly criticized in the international community for completely ignoring the fundamental human right to a fair trial for those convicted of capital drug offenses in their country [1].

Therefore, an analysis of the governmental use of capital punishment for drug crimes in the Middle East region and other authoritarian countries is important. The essence of expanding the comparative legal study to analyze such a sanction in these nations is to clarify the issues inherent in governmental methods for tackling the drug problem through legislative actions (e.g., the deterrent effects of the death penalty and lack of a fair trial) at a macro level, so as to provide effective and consistent ways to combat the worldwide drug problem.

23 It is estimated that more than 2,900 people were executed for drug offenses since 1979.

24 A death sentence will be automatically applied to those possessing more than 30 grams of heroin or five kilograms of opium. 


\section{Acknowledgements}

Special thanks to Professor Rolando V. del Carmen at Sam Houston State University for his assistance and suggestions.

\section{Conflict of Interest}

The authors declare no conflict of interest.

\section{References and Notes}

1. Tanya Hector. "The Death Penalty: No Solution to Illicit Drugs." Amnesty International. http://www.amnesty.org/es/library/asset/ACT51/002/1995/en/ab550293-eb32-11dd-92ac-295bdf9 7101f/act510021995en.pdf.

2. Peter Hodgkinson, Lina Gyllensten, and Diana Peel. Capital Punishment Briefing Paper. London: Centre for Capital Punishment Studies, 2010.

3. "Heroin addict parents kill child with drug overdose." Daily Mail, 25 October 2006. http://www.dailymail.co.uk/news/article-412824/Heroin-addict-parents-kill-child-drug-overdose.html.

4. "Thai drug organization blamed for killing 13 crew members on Chinese cargo ships.” BNO News, 10 October 2011. http://wireupdate.com/news/thai-drug-organization-blamed-for-killing13-crew-members-on-chinese-cargo-ships.html.

5. United Nations Office on Drugs and Crime (UNODC). World Drug Report 2011. Vienna: Division for Policy Analysis and Public Affair, 2011.

6. Lisa Zilney. Drugs: Policy, Social Costs, Crime, and Justice. Upper Saddle River: Pearson, 2010.

7. Isidore Obot. "Ethical and Iegal Issues in the Control of Drug Abuse and Drug Trafficking: The Nigerian Case.” Social Science \& Medicine 35 (1992): 481-93.

8. Rick Lines. The Death Penalty for Drug Offences: A Violation of International Human Rights Law. London: International Harm Reduction Association, 2007.

9. Diana Gordon. Return of the Dangerous Classes: Drug Prohibition and Policy Politics. New York: W W Norton, 1994.

10. Colman Lynch. "Indonesia's Use of Capital Punishment for Drug trafficking Crimes: Legal Obligations, Extralegal Factors, and the Bali Nine Case.” Columbia Human Rights Law Review 40 (2009): 523-27.

11. South Asia Human Rights Documentation Centre (SAHRDC). "No Justification for Singapore's Mandatory Death Penalty.” Human Right Features 6 (2006): 135.

12. “The Singapore Government's Response to Amnesty International's Report Singapore-The Death Penalty: A Hidden Toll of Executions.” Singapore Ministry of Home Affairs. Available online: www.mha.gov.sg/basic_content.aspx?pageid=74 (accessed on 13 November 2011).

13. Sidney Harring. "Death, Drugs and Development: Malaysia's Mandatory Death Penalty for Traffickers and the International War on Drugs.” Columbia Journal of Transnational Law 29 (1991): 365-401.

14. “Thailand's War on Drugs.” International Harm Reduction Association (IHRA). Available online: http://www.hrw.org/news/2008/03/12/thailand-s-war-drugs (accessed on 26 November 2011). 
15. William Schabas. “The Death Penalty and Drug Offences.” The Irish Centre for Human Rights \& the International Centre on Human Rights and Drug Policy. www.humanrightsanddrugs.org/wpcontent/uploads/2010/10/Prof-Schabas-Death-Penalty-for-Drug-Offences-Oct-2010-EN.pdf.

16. "The Death Penalty for Drug Offences: Global Overview 2012 Tipping the Scales for Abolition.” Harm Reduction International. www.ihra.net/files/2012/11/13/Death_penalty_2012_Tipping_the_ Scales_Web.pdf.

17. "Statistics of the Death Penalty in Thailand." Thai Department of Correction. Available online: http://www.correct.go.th/death.htm (accessed on 29 November 2011).

18. Sita Legac. "The Negative Impacts on the Global War on Drugs: Can International Drug Enforcement be Successful without Infringing on Human Rights?” Albany Government Law Review 3 (2010): 823-44.

19. Heather Kiefer. "Just Say No: The Case against Expanding the International Criminal Court's Jurisdiction to Include Drug Trafficking.” Loyola of Los Angeles International and Comparative Law Review 31 (2009): 157-81.

20. Raphael Francis Perl. "Congress, International Narcotics Policy, and the Anti-Drug Abuse Act of 1988.” Journal of Interamerican Studies and World Affairs 30 (1989): 19-52.

21. O'Hara, J.L., and Salleh, M.Z. "Recent Development in Legislative and Administrative Measures in Countries of the Association of South-East Asian Nations to Counter the Illicit Traffic in Drugs.” Bulletin of Narcotics 39 (1987): 51-56.

22. Charles S. Lanier, William J. Bowers, and James R. Acker. The Future of America's Death Penalty: An Agenda for the Next Generation of Capital Punishment Research. Durham: Carolina Academic Press, 2009.

23. International Narcotics Control Board (INCB). Report of the International Narcotics Control Board for 1994. New York: United Nations, 1995.

24. Richard Dieter. "The Death Penalty and Human Rights: U.S. Death Penalty and International Law.” Death Penalty Information Center. www.deathpenaltyinfo.org/Oxfordpaper.pdf.

25. "US Pushes Drug War Policies across Asia.” Organization of Common Sense for Drug Policy (CSDP). Available online: www.csdp.org/news/news/thailand.htm (accessed on 14 November 2011).

26. "International Covenant on Civil and Political Rights." Office of the United Nations High Commissioner for Human Rights (UNHCR). Available online: http://www.unhcr.org/refworld/ docid/3ae6b3aa0.html (accessed on 12 November 2011).

27. James H. Wyman. "Vengeance is Whose?: The Death Penalty and Cultural Relativism in International.” Law Journal of Transnational Law and Policy 6 (1997): 543-70.

28. "Understanding Federal and State Courts." United States Courts. Available online: http://www.uscourts.gov/EducationalResources/FederalCourtBasics/CourtStructure/Understandin gFederalAndStateCourts.aspx (accessed on 17 November 2011).

29. Drug Enforcement Administration (DEA). “DEA Mission Statement.” U.S. Department of Justice. Available online: http://www.justice.gov/dea/about/mission.shtml (accessed on 15 November 2011).

30. 21 United States Code (USC) Controlled Substances Act, enacted 27 October 1970.

31. Anti Drug Abuse Act of 1988, enacted 18 November 1988.

32. Furman v. Georgia, 408 U.S. 238, decided 29 June 1972. 
33. Kristine C. Mehok. “Act of Grace or Statutory Mandate? Funding for Counsel in State Clemency Proceedings Under the Anti-Drug Abuse Act of 1988.” Temple Law Review 78 (2005): 743-93.

34. Janet Bauman. “Conspiring Drug Kingpins: Twice in Jeopardy?” The University of Chicago Law Review 61 (1994): 197-223.

35. "Federal Death Penalty." Death Penalty Information Center. Available Online: http://www.deathpenaltyinfo.org/federal-death-penalty (assessed on 20 May 2013).

36. Eric Pinkard. "The Death Penalty for Drug Kingpins: Constitutional and International Implications.” Vermont Law Review 24 (1999): 1-27.

37. Kennedy v. Louisiana, 554 U.S. 407, decided 1 October 2008.

38. Calero-Toledo v. Pearson Yacht Leasing Co., 416 U.S. 663, decided 15 May 1974.

39. “Freeman v. United States (09-10245).” Legal Information Institute: Cornell University Law School. Available online: http://www.law.cornell.edu/supct/cert/09-10245 (assessed on 20 May 2013).

40. 18 United States Code (USC) Sentencing Reform Act, enacted 1 November 1987.

41. A Federal Rule of Criminal Procedure, enacted 1 December 1988.

42. "Freeman v. United States." Supreme Court of the United States Blog. Available Online: http://www.scotusblog.com/case-files/cases/freeman-v-united-states/ (assessed on 20 May 2013).

43. "The Singapore Legal System." Singapore Academy of Law. Available online: http://www.singaporelaw.sg/content/LegalSyst.html (accessed on 20 November 2011).

44. "Singapore Court System." The Law Society of Singapore. Available online: http://www.lawsociety.org.sg/forPublic/YoutheLaw/SingaporeCourtSystem.aspx (accessed on 20 November 2011).

45. Michael Hor. “The Death Penalty in Singapore and International Law.” Singapore Year Book of International Law and Contributors 8 (2004): 105-17.

46. Misuse of Drug Act (MDA), enacted 16 February 1973.

47. Yvonne McDermott. "Yong Vui Kong v. Public Prosecutor and the Mandatory Death Penalty for Drug Offences in Singapore: A Dead End for Constitutional Challenge?” International Journal on Human Rights 1 (2010): 35-52.

48. Ong Ah Chuan v. Public Prosecutor, AC 648, decided 15 October 1980.

49. Nguyen Tuong Van v. Public Prosecutor, I SGCA 47, decided 20 October 2004.

50. Constitution of Singapore, enacted 22 December 1965.

51. “Constitution.” Malaysia Government. Available online: http://www.malaysia.gov.my/ EN/Main/MsianGov/GovConstitution/Pages/Constitution.aspx (accessed on 24 November 2011).

52. "Malaysia Legal System." School of Law at Emory University. Available online: http://www.law.emory.edu/ifl/legal/malaysia.htm (accessed on 24 November 2011).

53. "Malaysia Judicial Authority." Malaysia Government. Available online: http://www.malaysia.gov.my/EN/Main/MsianGov/GovGovernance/GovJudicialAuthority/Pages/G ovJudicialAuthority.aspx (accessed on 20 November 2011).

54. "Human rights.” Malaysia Government. Available online: http:/www.malaysia.gov.my/EN/ Main/MsianGov/GovConstitution/GovHumanRights/Pages/Human_Rights.aspx (accessed on 22 November 2011). 
55. “Malaysia Country Report 2009.” National Anti Drugs Agency (NADA). http://www.aipasecretariat.org/wp-content/uploads/2010/07/Malaysia-Country-Report.pdf.

56. Dangerous Drug Act (DDA), enacted in 1952 (Ordinance No. 30 of 1952).

57. Peter Hiett. "Brian Chambers and Kevin Barlow Executed in Malaysia.” The Guardian, 7 July 1986. http://www.guardian.co.uk/theguardian/1986/jul/07/.

58. Edmund Ngo. "Death Penalty may be Scrapped for Drug Offences.” The Star Online, 21 October 2012. http://thestar.com.my/news/story.asp?file=/2012/10/21/nation/12204175\&sec=nation.

59. Tim Lindsey. "Indonesian Trial Process and Legal System.” Asian Law Centre at the University of Melbourne. http://www.law.unimelb.edu.au/files/dmfile/Indonesians_Trial_Process_and_Legal_ System_Background_Notes1.pdf.

60. Eddy Damian, and Robert N. Hornick. “Indonesia’s Formal Legal System: An Introduction.” The American Journal of Comparative Law 20 (1972): 492-530.

61. Fachri Bey. "Three Most Important Features of Indonesian Legal System That Others Should Understand.” Paper presented at the IALS Conference. http:/www.ialsnet.org/meetings/enriching/ bey.pdf.

62. “Indonesia." U.S. Department of State. Available online: http://www.state.gov/r/pa/ei/bgn/ 2748.htm (accessed on 3 December 2011).

63. Law No. 22 on Narcotics, enacted in 1997.

64. AAP. "Rush Driven to Self Harm.” news.com.au, 24 July 2007. http://www.news.com.au/ features/rush-driven-to-self-harm/story-e6frfl3i-1111114286111.

65. Cindy Wockner. “Only Prayers Left on Death Row.” news.com.au, 3 November 2007. http://www.news.com.au/features/only-prayers-left-on-death-row/story-e6frfl3i-1111114866149.

66. AAP. “Bali Nine Can’t Challenge Laws.” news.com.au, 30 October 2007. Available online: http://www.news.com.au/features/bali-nine-cant-challenge-laws/story-e6frfl3i-1111114758194 (accessed on 7 December 2011).

67. Herald Sun. "Rudd to Appeal for Bali Nine." news.com.au, 12 December 2007. http://www.news.com.au/features/rudd-to-appeal-for-bali-nine/story-e6frfl3i-1111115091327.

68. Ngamnet Triamanuruck, Sansanee Phongpala, and Sirikanang Chaiyasuta. "Overview of Legal Systems in the Asia-Pacific Region: Thailand.” Cornell Law School. Available online: http://scholarship.law.cornell.edu/lps_lsapr/4/ (aceessed on 15 December 2011).

69. “The World Fact Book: Thailand.” Central Intelligence Agency (CIA). Available online: http://www.cia.gov/library/publications/the-world-factbook/geos/th.html (accessed on 15 December 2011).

70. "World Law: Thailand." School of Law at the University of Pittsburgh. Available online: http://jurist.law.pitt.edu/world/Thailand.html (accessed on 23 November 2013).

71. Narcotic Act, B.E. 2522, enacted 22 April B.E. 2522 (1979).

72. Narcotics Addict Rehabilitation Act, B.E. 2545 (2002), enacted 3 March B.E. 2546 (2003).

73. Suppression of Offenders in an Offense Relating to Narcotics, B.E. 2534 (1991), enacted 19 September B.E. 2534 (1991).

74. “Thai Human Rights Plan.” Thai Human Rights Organization. Available online: http://deathpenaltythailand.blogspot.com (accessed on 19 December 2011). 
75. “Man loses bid for royal pardon.” Peterborough Telegraph, 19 November 2011. Available online: http://www.peterboroughtoday.co.uk/news/local/man_loses_bid_for_royal_pardon_1_3263262 (accessed on 28 December 2011).

76. "Death Penalty Report Launch.” Harm Reduction International. Available Online: http://www.ihra.net/contents/761 (assessed on 25 May 2013).

(C) 2013 by the authors; licensee MDPI, Basel, Switzerland. This article is an open access article distributed under the terms and conditions of the Creative Commons Attribution license (http://creativecommons.org/licenses/by/3.0/). 